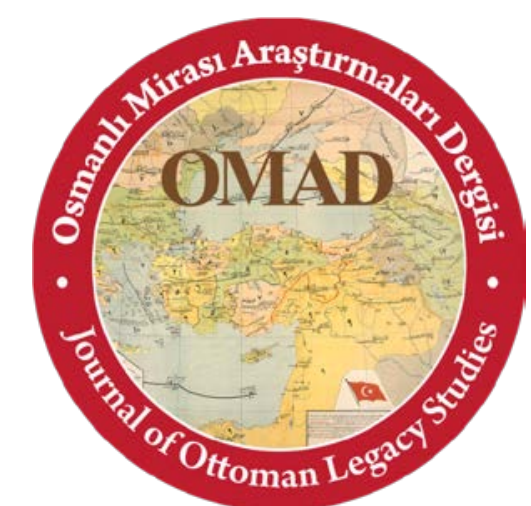

Osmanlı Mirası Araştırmaları Dergisi / Journal of Ottoman Legacy Studies

ISSN 2148-5704

www.osmanlimirasi.net

osmanlimirasi@gmail.com

Cilt 6, Sayı 15, Temmuz 2019 / Volume 6, Issue 15, July 2019

\title{
IMPROVEMENTS AND PUBLIC WORKS IN THE HIJAZ PROVINCE “THE RULE OF SULTAN ABDULHAMID II"
}

Hicaz Vilayetinde Islahat ve Bayındırlık "Sultan II. Abdülhamid Dönemi"

Makale Türü/Article Types : Araştırma Makalesi/Research Article

Geliş Tarihi/Received Date : 29.04.2019

Kabul Tarihi/Accepted Date : 26.06.2019

Sayfa/Pages : 329-351

DOI Numaras1/DOI Number : http://dx.doi.org/10.17822/omad.2019.129

\section{HASAN BARLAK}

(Dr. Öğr. Üyesi), Sinop Üniversitesi, Fen-Edebiyat Fakültesi, Tarih Bölümü, Sinop / Türkiye, email: hbarlak@sinop.edu.tr, ORCID: https://orcid.org/0000-0001-7252-5584

\section{Atıf/Citation}

Barlak, Hasan, "Improvements and Public Works in the Hijaz Province "The Rule of Sultan Abdulhamid II", Osmanlı Mirası Araştırmalan Dergisi [Journal of Ottoman Legacy Studies], 6/15, 2019, 329-351. 

Osmanlı Mirası Araştırmaları Dergisi (OMAD), Cilt 6, Sayı 15, Temmuz 2019.

Journal of Ottoman Legacy Studies (JOLS), Volume 6, Issue 15, July 2019.

ISSN: $2148-5704$

\title{
IMPROVEMENTS AND PUBLIC WORKS IN THE HIJAZ PROVINCE “THE RULE OF SULTAN ABDULHAMID II"*
}

\author{
Hicaz Vilayetinde Islahat ve Bayındırlık "Sultan II. Abdülhamid Dönemi"**
}

\section{HASAN BARLAK}

\begin{abstract}
The Ottoman restructuring process that began in the first half of the $19^{\text {th }}$ century continued without pausing during the rule of Sultan Abdülhamid II. He waged a significant struggle to develop the empire through the reform and renovation activities that he carried out across the country. The Hijaz has a special place among the provinces that the Sultan focused on for investment. Мecca, where the Hajj as one of the main worships of Islam is performed, used to be visited by tens of thousands of Muslims each year. Serving Haramayn was already an Ottoman state tradition. However, the new developments around the world led Abdülhamid II, the caliphate-sultan, to attribute a special importance to the Hijaz. The Sultan wanted to ensure that the people who come to the Hijaz leave it with positive impressions and thus to secure the support to the all of Muslims. Through his activities in Haramayn, Abdülhamid II also targeted to bring a more Ottoman character to the Hijaz. During his thirty-three years of rule, many and various innovations and improvements in the Hijaz from administrative initiatives and training activities to investments of transportation and communication and health services were implemented and significant efforts were made for developing the province. The Hamidiye-Hijaz Railway has a special place among the investments made in the region. Other than that, many services were carried out in the Hijaz like new governmental buildings, hospitals, schools, waterways, security units and a guesthouse for poor pilgrims, and a great effort was taken to improve the province.
\end{abstract}

Keywords: Abdülhamid II, Haramayn, Improvements, Public Works, Hijaz Railway

Öz: Osmanlı Devleti’nde 19. yüzyılın ilk yarısında başlayan yeniden yapılanma süreci Sultan II. Abdülhamid döneminde hız kesmeden devam etmiştir. II. Abdülhamid'in ülke genelinde giriştiği islahat ve yenileşme faaliyetleri ile imparatorluğu kalkındırma yolunda kayda değer bir mücadelesi olmuştur. Hicaz, padişahın yatırım yapmak üzere yöneldiği vilayetler arasında belirgin bir yere sahiptir. İslam'da temel ibadetlerden biri olan haccın yerine getirildiği Mekke, her yıl on binlerce Müslüman tarafından ziyaret ediliyordu. Haremeyn'e hizmet etmek de zaten bir Osmanlı devlet geleneği idi. Bununla birlikte dünyadaki yeni gelişmeler II. Abdülhamid'in halife-sultan olarak Hicaz’a özel bir ehemmiyet vermesini beraberinde getirmiştir. Padişah, Hicaz'a gelen insanların buradan olumlu intibalarla ayrılmalarını sağlamak ve bu sayede Müslüman kamuoyunu yanında tutmak istemiştir. II. Abdülhamid Haremeyn'deki icraatları ile Hicaz'a daha ziyade Osmanlı bir karakter kazandırmayı da hedeflemiştir. Onun otuz üç yıllık iktidarı döneminde Hicaz'da idari girişimlerden eğitim çalışmalarına, ulaşım ve haberleşme yatırımlarından sağlık hizmetlerine kadar çok çeşitli yenilik ve iyileştirmeler yapılmış, vilayetin bayındır bir hale getirilmesi için ciddi bir uğraş sergilenmiştir. Bölgeye yapılan yatırımlar arasında Hamidiye-Hicaz Demiryolu'nun özel bir yeri vardır. Bundan başka Hicaz'a yeni devlet binaları, hastaneler, okullar, su yolları, güvenlik birimleri ve fakir hacılar için misafirhane gibi pek çok hizmet götürülmüş ve vilayetin her yönden ihya edilmesi için büyük bir gayret gösterilmiştir.

Anahtar Kelimeler: II. Abdülhamid, Haremeyn, Islahat, Bayındırlık, Hicaz Demiryolu

\footnotetext{
* This study is based on the author's doctoral thesis with the title "Dinî ve Siyasî Yönden Osmanlı Devleti İdaresinde Hicaz (1876-1909)," [Hijaz Under The Rule of Ottoman Empire in Terms of Religion and Politics (1876-1909)], Ondokuz Mayıs University, Institute of Social Sciences, Samsun 2013.

** Bu çalışma yazarın “Dinî ve Siyasî Yönden Osmanlı Devleti İdaresinde Hicaz” (1876-1909), başlıklı doktora tezinden üretilmiştir: Ondokuz Mayıs Üniversitesi, Sosyal Bilimler Enstitüsü, Samsun 2013.
} 


\section{Introduction}

At the end of the $17^{\text {th }}$ century, the Portuguese, who sailed around Cape of Good Hope started to pose a threat against Muslim states in the coasts of Indian Ocean, East Africa, Red Sea and the Arabian Sea. However, the fact that Ottomans advanced into Syria and Egypt caused future plans of the Portuguese, which included the possibility that the holy cities of Islam, Mecca and Medina, might be occupied, to fall through. The victory that Yavuz Sultan Selim won in Mercidabık and Ridaniye resulted in Ottoman-Turkish Reign in the region, which lasted nearly for four hundred years. ${ }^{1}$ After Egypt was conquered, The Emir of Mecca, Sherif Berekat II, sent his son Ebu Numey to Cairo accompanied by a committee who had the keys to the Kaba (at Mecca) and the sacred relics with them (July 6, 1517). Upon the pledge of the Sherif of Mecca that he would obey, Sultan Selim sent royal diploma (ber'at) and a robe of honour (hil'at) for Sherif Berekat as a symbol of emirate, and 200.000 gold money and a lot of grain and provisions for the people in Mecca and Medina. When Ebu Numay came back to Mecca, Sherif Berekat delivered a sermon in the name of Ottoman Sultan with the robe of honour on him, which was sent by Sultan Selim. Thus, Mecca and Medina was under the rule of Ottomans, and the Ottoman Sultans earned the title of Khadim al-Haramayn (The Protector or Servitor of the Two Holy Cities), which made them twice as much honourable in the world of Islam. ${ }^{2}$ Ottomans, after having had the rule of these two cities, they always had a great interest and respect for these cities and made huge expenditure on Mecca and Medina. ${ }^{3}$

During the classical terms of the Ottomans, the Sultans provided much more services for religious centres in Hijaz; especially they made extensions to al-Masjid al-Haram (Grand Mosque) in Mecca and al-Masjid an-Nabawi (Prophet's Mosque) in Medina and restored them. With these improvements and restoration activities, they improved Haramayn on one hand, and they meant to show how powerful Ottoman State was to the Muslims who came from various parts of the World to Hijaz on the other. Although there are many examples of these extensions and ornamentation, I'll give some examples just to introduce some of them. Besides the declarations of the God's unity embroidered with black silk on the cloth of the Kaba and the versus embroidered with pure gold on the arch around the Kaba, ${ }^{4}$ on the part of the arch facing Makam-ı Hanefi was the name of the Sultan, his titles and his ancestors respectively. ${ }^{5}$ The minarets of al-Masjid al-Haram, five of which were built by Abbasids, the sixth by Mamluks and the seventh by Ottomans, the latter had the name Süleymaniye, ${ }^{6}$ and it was built next to Süleymaniye Madrasa. ${ }^{7}$

Masjid al-Haram was repaired to a considerable extent at the time of Süleyman the Magnificent 1525 (1540-1552). And most of the pillars and porticos were replaced with new ones. The Masjid al-Haram took its final shape architecturally at the time of Sultan Selim II and Sultan Murad III. In 1576, the flat wooden roof on porticos around the Masjid al-Haram was removed, and instead many conical domes were built in accord with the Ottoman architectural style. In this period, except for the materials prepared and sent from Istanbul and Egypt, a series

\footnotetext{
${ }^{1}$ Jane Hathaway, Karl K. Barbir'in katkılarıyla, Osmanlı Hâkimiyetinde Arap Toprakları, Çeviren: Gül Çağalı Güven, Türkiye İş Bankası Kültür Yayınları, İstanbul 2016, pp. 49-52.

${ }^{2}$ Hoca Sadettin Efendi, Tacü’t-Tevarih, Hazırlayan: İsmet Parmaksızoğlu, Volume: 4, Kültür Bakanlığı Yayınları, Ankara 1992, pp. 332-333; Feridun M. Emecen, "Hicaz'da Osmanlı Hâkimiyetinin Tesisi ve Ebu Nümey”, İ̈̈ Edebiyat Fakültesi, Tarih Enstitüsü Dergisi, Ayrı basım, Issue: 14, 1994, p. 89; Carter Vaughn Findley, Turkey, Islam, Nationalism, and Modernity, Yale University Press, New Haven \& London 2010, p. 138.

${ }^{3}$ Suraiya Faroqhi, Hacılar ve Sultanlar, Çeviren: Gül Çağalı Güven, Tarih Vakfı Yurt Yayınları, İstanbul 2008, p. 106.

${ }^{4}$ Hicaz Vilayeti Salnamesi, Hicaz Vilayeti Matbaas1, h. 1309 (1891-1892), pp. 190-191.

${ }^{5}$ Eyüb Sabri, Mir'âtü'l-Haremeyn (Mir'ât-ı Mekke), Volume: 1, Bahriye Matbaası, Kostantıniyye 1301, p. 864.

6 İbrahim Rifat Paşa, Mir'âtü'l-Haremeyn ev er-Rehelâtü'l-Hicaziyye ve'l-Hacc ve Meşa'iruhu'd-Dîniyye, Volume:1, Matba’atü Dâri'l-Kütübi'l-Mısriyye, Kahire m. 1925 - h. 1344, p. 234-235.

${ }^{7}$ İsmail Hakkı Uzunçarşıl1, Mekke-i Mükerreme Emirleri, Türk Tarih Kurumu Yayınları, Ankara 1972, p. 3.
} 
of changes were made spending 110.000 dinars. ${ }^{8}$ The glorious pulpit in the hall of the Masjid alHaram was also sent by Süleyman the Magnificent in h. 966 (1558-1559). The pulpit made of marble is a genuine work of art with its elaboration. On the side of the pulpit facing the Kaba are the sentences "Praise be to Allah, Lord of the Worlds. Süleyman had a pulpit build in the secure city." Just opposite of it, it's written, "No doubt it is by Süleyman and no doubt it start with the name of Allah. ${ }^{9}$ The Gracious and the Magnificent told the truth, year: 966 h." 10

The first changes to al-Masjid an-Nabawi started at the time of Süleyman the Magnificent, and during the time of the Sultans after him, various innovations and restorations were carried out. By the order of Sultan Mahmud II, al-Masjid an-Nabawi had undergone major renovations between 1817-1837. During the renovations, new pillars were erected and a new stone dome was built over Hücre-i Saadet instead of the one which was built by the ordinance of Mamluki Sultan Kayıtbay. The dome covered by lead and painted in green was named Kubbetu'l-Hadra owing to its colour. The most comprehensive renovation and restoration carried out in al-Masjid an-Nabawi by Ottoman State was at the time of Sultan Abdülmecid. During the construction activities, which began in 1850 and ended in 1861, al-Masjid anNabawi was renewed thoroughly. The Masjid was enlarged, the number of porticos were increased and the Masjid was ornamented with Celi Sülüs style of writings. Except for the materials sent from İstanbul and Egypt for this construction, thanks to which al-Masjid anNabawi was renewed and became more attractive, 700.000 mecidiyes was spent. ${ }^{11}$

Al-Masjid an-Nabawi had five doors, one of which was Babü'l Mecidi to the North. ${ }^{12}$ It had five minarets, two of which were called Mecidiye and Aziziye. ${ }^{13}$ Nabi's Mihrab, Uthman's Mihrab, Süleyman's Mihrab ${ }^{14}$ and Mihrab-ı Teheccüd (Mihrabu'n-Nisa) were the four mihrabs of the mosque. ${ }^{15}$ In h. 998 (1589-1590), Sultan Murad IV, sent a minbar to al-Masjid an-Nabawi which was a masterpiece with the ornamentations and decorations on it. It was designed as the one with twelve steps, three of which were outside the door of it and nine were inside. The minbar with features similar to that of Ottoman Selatin Mosques is about seven meters high with a dome which has distinctive golden ornamentation on it. ${ }^{16}$ There is a special part to the right of the large hall designed for women, and on the pillars in the middle of the hall are lambs and chandlers with electricity. And there was Sultan's tughra on the arches. Sures, verses and odes were written on the walls, and Turkish carpets with patterns of small rugs were laid on the floor. ${ }^{17}$ As it can be noticed easily, until the middle of the nineteenth century, the services in Haramayn centered on Masjid al-Haram and al-Masjid an-Nabawi. Yet, after the Tanzimat (the Reforms), together with administrative regulations, more general services would take place.

Primarily, when we look at Ottoman administration between 1840-1908 in Hijaz, it would be right to say that it was really successful administratively, politically, socially, and etc. ${ }^{18}$ In

\footnotetext{
${ }^{8}$ Nebi Bozkurt, Mustafa Sabri Küçükaşcı, "Mescid-i Harâm”, Türkiye Diyanet Vakfi İslâm Ansiklopedisi, Volume: 29, Türkiye Diyanet Vakfi, Ankara 2004, p. 274.

9 This statement has been taken from the Quran. "Lo! it is from Solomon, and it is: In the name of Allah the Compassionate the Merciful”: 27 Sûrah An-Naml, 30, The Holy Qur'an With English Translation, Staff of Translation: Ali Özek, Nureddin Uzunoğlu, at al., İlmî Neşriyat, İstanbul 1992.

10 İbrahim Rifat Paşa, op. cit., v. 1, pp. 253-254; Muhammed Lebîb el-Betenûnî, er-Rihletü'l-Hicaziyye, Mektebetü’sSekafeti'd-Diniyye, Kahire, p. 158.

${ }^{11}$ Nebi Bozkurt, Mustafa Sabri Küçükaşcı, "Mescid-i Nebevî”, Türkiye Diyanet Vakfi İslâm Ansiklopedisi, Volume: 29, Türkiye Diyanet Vakf1, Ankara 2004, pp. 283-284.

12 el-Betenûnî, op. cit., p. 320.

${ }^{13}$ Eyüb Sabri, Mir'âtü'l-Haremeyn (Mir'ât-ı Medîne), Volume: 2, Bahriye Matbaası, Kostantıniyye 1304, p. 70.

${ }^{14}$ The mihrab is made of marble, and it was a gift from Suleyman the Magnificent: Hicaz Vilayeti Salnamesi, Mekkei Mükerreme, h. 1306/1888-1889, p. 237.

${ }^{15}$ Eyüb Sabri, Mir'âtü'l-Haremeyn (Mir'ât-ı Medîne), v. 2, p. 68.

${ }^{16}$ İbrahim Rifat Paşa, op. cit., v. 1, p. 471; N. Bozkurt, M. S. Küçükaşcı, “Mescid-i Nebevî”, op. cit., v. 29, p. 285.

${ }^{17}$ See İbrahim Rifat Paşa, op. cit., v. 1, pp. 456-459.

${ }^{18}$ William Ochsenwald, Religion, Society and the State in Arabia The Hijaz Under Ottoman Control, 1840-1908, Ohio State University Press, Columbus 1984, p. 221.
} 
terms of administration Hijaz, formerly an eyalet, was transformed into a vilayet. After mutasarriflk in 1872, it was restored to its former status in $1875 .{ }^{19}$ The changes in Hijaz between classical period and the period after the Tanzimat was relatively limited compared to that of other provinces. Although "1871 Province Regulation" had a general content, it was partly applied in the provinces like Hijaz, which had a special status in classical Ottoman administration. ${ }^{20}$. Hijaz province in Ottoman administrative structure was the region surrounded by Najd in the East, Red Sea in the West, Asir sancak of Yemen province in the South, Syria province, the Jerusalem sancak, Egypt Khediviate in the North. ${ }^{21}$ Hijaz province, which had $250.000 \mathrm{~km}^{2}$ of area ${ }^{22}$ consisted of sancaks (cities) of Mecca, Medina and Jidda. ${ }^{23}$ Smaller settlements like town and township were Yanbu al-Bahr, Lebid, Taif, Rabigh, ${ }^{24} \mathrm{Lit}^{25}$, (Ma'mûret-ul Hamîd) ${ }^{26}$, Wajh, Suwarqiyyaa ${ }^{27}$ and Khaybar. ${ }^{28}$ Arabic was spoken language in Hijaz, but most of the people of Mecca, Medina and Jidda were familiar with Turkish as well. ${ }^{29}$ It is estimated that, taking the end of the 19th century into consideration, the total population of Hijaz-including cities, towns, villages and countryside was between 400.000 and $800.000 .{ }^{30}$

The centre of Hijaz province was Meccan sancak (Mekke-i Mükerreme). ${ }^{31}$ Valis (governors) appointed to Hijaz in charge of civil, financial and other administrative issues were chosen from among the statesmen of higher rank like müşirs or viziers. ${ }^{32}$ Valis, mostly of military origin ${ }^{33}$ also had the title Şeyhulharem-i Mekki. ${ }^{34}$ The government system in Hijaz was different from that of other Ottoman cities, due to the fact that Emirate, an old conventional institution, also took part in governing the province. Meccan Emirate was responsible for taking care of services of the noble, the Bedouin and other people of the region. The Sublime Porte had Emir help him with the administration of Bedouins especially, and he would appoint one of the sherifs, whom he regarded suitable for the position as the Emir of Mecca. ${ }^{35}$ However, after the Tanzimat, Ottoman State preferred policies that would give the governors of the province more power. On the other hand, the unforgettable pain caused by Wahhabis and the plans of the European States, especially England, about Middle East made Ottoman State adopt a more careful attitude towards Hijaz. The fact that tens of thousands of people, including a large number of colony Muslims, came to Mecca every year for Hajj, especially making use of the

${ }^{19}$ See Zekeriya Kurşun, “Osmanlı Devleti İdaresinde Hicaz (1517-1919)”, Osmanlı, Volume: 1, Editör: Güler Eren, Yayın Kurulu Başkanı: Halil İnalcık, Yeni Türkiye Yayınları, Ankara 1999, pp. 321-323.

${ }^{20}$ İlber Ortaylı, Tanzimat Devrinde Osmanlı Mahallî Ídareleri (1840-1880), Türk Tarih Kurumu Yayınları, Ankara 2000, p. 64.

${ }^{21}$ Hicaz Vilayeti Salnamesi, Düzenleyen: Cidde Vali Kaimmakamı Muhammed Arkî Bey, Mekke-i Mükerreme, h. 1305 (1887-1888), p. 103; Hicaz Vilayeti Salnamesi, h. 1306 (1888-1889), p. 135; Hicaz Vilayeti Salnamesi, h. 1309 (1891-1892), p. 138.

${ }^{22}$ M. Nasrullah, M. Rüşdü, M. Eşref, Osmanlı Atlası (XX. Yüzyıl Başları), Hazırlayanlar: Rahmi Tekin, Yaşar Baş, Osmanlı Araştırmaları Vakfi Yayınları, İstanbul 2003, p. 105.

${ }^{23}$ Hicaz Vilayeti Salnamesi, h. 1305 (1887-1888), p. 103; Hicaz Vilayeti Salnamesi, h. 1306 (1888-1889), p. 135; Hicaz Vilayeti Salnamesi, h. 1309 (1891-1892), p. 138.

${ }^{24}$ Salname, Def'a 31, 1293 (1876-1877), p. 254.

${ }^{25}$ Salname-i Devlet-i Aliyye-i Osmaniye, 45. Sene, Matbaa-i Âmire, Dersaadet h. 1307 (1889-1890), p. 438.

${ }^{26}$ Salname-i Devlet-i Aliyye-i Osmaniye, 46. Sene, Matbaa-i Âmire, Dersaadet h. 1308 (1890-1891), p. 428.

27 Salname-i Devlet-i Aliyye-i Osmaniye, 54. Sene, Âlem Matbaası ve Mahmud Bey Matbaası, İstanbul h. 1316 (1898/1899), pp. 392-394.

${ }^{28}$ Salname-i Devlet-i Aliyye-i Osmaniye, 64. Sene, Matbaa-i Ahmed İhsan, Dersaadet h. 1326 (1908-1909), p. 697.

${ }^{29}$ Hicaz Vilayeti Salnamesi, h. 1306 (1888-1889), p. 139.

${ }^{30}$ W. Ochsenwald, Religion, Society and the State in Arabia, p. 17.

${ }^{31}$ Hicaz Vilayeti Salnamesi, h. 1309 (1891-1892), pp. 142, 183.

${ }^{32}$ Eyüb Sabri, Mir'atü'l-Haremeyn (Mir'ât-ı Mekke), v. 1, p. 25.

33 Saleh Muhammad al-Amr, The Hijaz Under Ottoman Rule 1869-1914: Ottoman Vali, The Sharif of Mecca, and The Growth of British Influence, Riyad University Publications, 1974, p. 74.

${ }^{34}$ Salname-i Devlet-i Aliyye, h. 1326 (1908-1909), p. 692; Hicaz Vilayeti Salnamesi, Mekke-i Mükerreme h. 1303 (1885-1886), p. 59; Hicaz Vilayeti Salnamesi, h. 1309 (1891-1892), p. 150.

${ }^{35}$ Eyüb Sabri, Mir'âtü'l-Haremeyn (Mir'ât-ı Mekke), v. 1, p. 25; Salname-i Devlet-i Aliyye-i Osmaniye, 41. Def'a, Mahmud Bey Matbaası, Dersaadet h. 1303 (1885-1886), p. 471; Uzunçarş11, op. cit., p. 25; Kemal H. Karpat, İslâm'ın Siyasallaşması, Çeviren: Şiar Yalçın, İstanbul Bilgi Üniversitesi Yayınları, İstanbul 2005, p. 451. 
advantages of developed sea transportation, made it necessary to make new investments in Hijaz, to introduce a series of reforms and have a more effective representation in the Haramayn. In addition, although in investment for Hijaz priority was given to places regarded as important in religion in earlier periods, during the time of Sultan Abdülhamid II, most of the investments were made in administrative, social and military domains. In any case, Abdülhamid II, attaching substantial importance to Haramayn, wanted to transform Hijaz into a developed Ottoman city.

\section{Public Works and Public Investments}

\subsection{Government Office, Health Organisations and Water Services}

Ottoman State, right after the Tanzimat, increased all sorts of activities more and more in military, legal and administrative domains in order to develop the state, create more prosperous society, and modernise it. However, the fact that a great majority of Arabs maintained their traditional life styles in Ottoman Arab geography hindered attempts of modernisation to a large extent in provinces like Hijaz. ${ }^{36}$ Despite this, the Sublime Porte did all that it could in order to have stronger bonds with Hijaz, this distant city, and increase the level of prosperity there. At the time of Abdülhamid II, the first thing to be noticed was renovation of state offices and increasing them in number. It can be said that, possibly, the most remarkable among of them was the government office in Mecca, which was rebuilt in h. 1302 (1886-1887). It was built on the land before Babü'l-Veda, Haram al-Sharif, which belonged to the state. The public office entitled Hamidiye was designed like a small model of Bâb-ı Vâlâ-yı Seraskerî. ${ }^{37}$ Meanwhile, the barracks, police stations and military installations built in other important parts of the cities like Mecca, Medina and Hijaz during this period can be evaluated as the supportive works for the administrative power. ${ }^{38}$

As regards health services, a medical office, a hospital with 40 beds and a drugstore were built in Mina (h. 1300 / 1882-1883). It was ordered that a second floor be built over the present Gureba-yı Muslimin Hospital in Mecca, which was renovated by Bezm-i Âlem Valide Sultan. ${ }^{39}$ Health services were not limited to these. These services were carried out in a timely manner, especially during Hajj season. To improve the health conditions in Hijaz, various measures were taken, and there was a significant medical reconstruction in the province. In 1895, having worked on the report prepared by Kasım İzzeddin, a physician in Mecca, Hijaz Medical Institution (Hicaz Sihhiye Teşkilatı) was built. ${ }^{40}$ Evaluations made by Emir Şekib Arslan, who went on a pilgrimage to Mecca in 1929, would be a good reference to show the magnitude of the services provided by Ottoman Government regarding this issue. Having spoken highly of the Works done in Hijaz by İzzeddin Bey, Emir Şekib Arslan added that the institution built in his time was still in service, and new works were carried out by following Kasım İzzeddin closely. ${ }^{41}$

One of the issues that the government gave priority to was the water supply system. To this end, during the time when Osman Nuri Pasha was the vali, a great deal of effort was made to reconstruct Ayn-ı Zübeyde watercourse, which contributed substantially to meet the need for water in the province. The Works conducted by the construction committee under the

\footnotetext{
36 Cemaleddin Efendi II. Abdülhamid'in Şeyhülislâmı, Siyasi Hatıralarım, Hazırlayan: Selim Kutsan, Nehir Yayınları, İstanbul 2005, p. 25.

${ }^{37}$ Muhammed el-Emîn el-Mekkî, Hulefa-i I'zam-ı Osmaniye Hazeratının Haremeyn-i Şerifeyndeki Âsar-ı Mebrûre ve Meşkûre-i Hümayunlarından Bahis Tarihi bir Eserdir, Matbaa-i Osmaniye, Dersaadet r. 1318 (1902), pp. 13-14.

${ }^{38}$ M. E. el-Mekkî, op. cit., pp. 10-11, 15-16.

${ }^{39}$ M. E. el-Mekkî, op. cit., pp. 13, 17.

${ }^{40}$ Kasım İzzeddin, Hicaz Sihhiye İdaresi Senevî Rapor: Hicaz'da Teşkilat ve Islahat-ı Sihhiye 1329 Senesi Hacc-ı Şerifi, Matbaa-i Âmire, İstanbul 1328, pp. 14-16; Gülden Sarıyıldı, Hicaz Karantina Teşkilâtı (1865-1914), Türk Tarih Kurumu Yayınları, Ankara 1996, pp. 113-119.

${ }^{41}$ Emîr Şekib Arslan, Hicaz Yolculuğu Hac Hâtıraları 1910-1940, Çeviren: Adem Yerinde, İnkılâb Yayınları, İstanbul 2012, p. 28.
} 
presidency of Osman Nuri Pasha ${ }^{42}$ started at Vadi-i Numan, a place at eight hours distance from Mecca. More than 3.000 workers were employed for the construction, which continued day and night for four years. In the end, the watercourse were repaired and reconstructed so that there would be no problem for many years. Except for these, 18 big water houses and fountains were built in Mecca, and a lot of fountains with taps were built around Haram al-Sharif for pilgrims to perform ablution. A spout of water was provided for each of the following; artillery barracks, the Hospital of Gureba, Haseki Sultan Imaret, government office, printing house, telegraph office, military bakery, security police stations and public baths. During the pilgrimage season, a waterskin of water was sold for 1 riyal in the past, but now it was only 20 paras. Making the expenditure for the construction, a private committee was established under the presidency of Abdurrahman Sirac Efendi, Hanafi Mufti of Mecca, and this committee made all the expenditures (h.1301 / 1883-1884). ${ }^{43}$

After the decision was made about the cleaning and repairs of the watercourse of Ayn- $\iota$ Zübeyde watercourse, works were carried out permanently by using the 200.000 kurush allocated by Hijaz Treasury. In the meantime, with the contribution of the prominent figures in Mecca, effective campaigns were arranged and many people used every means available to meet the needs of pilgrims for water. Moreover, provided that the money raised was not enough to do all these things, it was declared that 40.000-50.000 kurush would be given by the Sultan Padishah as a Caliph. ${ }^{44}$ In the second half of $19^{\text {th }}$ century, the number of pilgrims increased, which resulted in making more effort and spending more money to meet their needs, and the government took some remedial actions within this direction.

After the completion of Ayn-1 Zübeyde construction, Osman Nuri Pasha took action to meet the need for water in Jidda. Within three years, he could manage to bring Veziriye Water from Ruğame, two hours walk away from Jidda, employing 3.500 workers and getting help from the local people. Thus, the people of Jidda and pilgrims didn't have to drink pit waters. Water houses with fountains were built in the quarters of Jidda and Kışla-yı Humayun, public office and military hospital were provided with a spout of water for each. Many Ottoman statesman made significant contribution to the construction, of which engineering studies were conducted by Osman Pasha. Meanwhile, water pools in Arafat were also cleaned and repaired (h. 1303/ 1885-1886). ${ }^{45}$

People were suffering from shortage of water, especially in the years when it didn't rain, as the water resources were insufficient in Hijaz. Furthermore, due to the increase in population in Hajj season much more water was needed. Considering these circumstances, Ottoman government dealt with the water shortage problem in Hijaz wholeheartedly, and took action to overcome the perennial water problem in order to get rid of the problem, the Sublime Porte wanted to make use of technology and tried to meet the need for drinking water to some extend by distilling sea water. Jeddah and Yanbu were the places where water shortage was a serious problem. As both of these cities were near the sea, it was decided that new methods should be implemented there. With the efforts of government authorities in the province and the directives of Abdülhamid II, water instilling machines were brought to Jeddah and Yanbu. Thus, the first

\footnotetext{
${ }^{42}$ The members of the commission are: Sadık Bey, Erkan-1 Harbiye colonel; Münir Bey, Erkan-1 Harbiye major; Abdullah Bey, Lieutenant Major; Nasrullah, Şevki, Osman Nuri, infantry captains and Mülazım Mehmed Efendi; Captain Tevfik Ağa and Ahmed Şemseddin Bey, The civil service engineer: M. E. el-Mekki, op. cit., p. 11.

${ }^{43}$ M. E. el-Mekkî, op. cit., pp. 11-12.

${ }^{44}$ Türkiye Cumhuriyeti Cumhurbaşkanlığı Devlet Arşivleri Başkanlığı Osmanlı Arşivi (BOA), Irade Dahiliye (İ.DH), Dosya No: 800, Gömlek No: 64862, Tarih: 22 Rebiulevvel 1297 (4 Mart 1880).

${ }^{45}$ M. E. el-Mekkî, op. cit., pp. 12-13.
} 
water treatment plant was founded in Jeddah, Hijaz. At the beginning of $20^{\text {th }}$ century, thanks to it, the need for water in the province was met to some extent. ${ }^{46}$

One of the important services in Hijaz was that Mina was supplied with water. Ayn-1 Zübeyde water used to run through Mafcer Valley, and it was possible to transfer some water to Mina by using technology. Osman Nuri Pasha, who wanted to do this, had a vapour machine built at Tersane-i Amire, and thanks to it, he could manage to bring water to the town Mina from a mountain of 300 meters high. Thus, in Mina, where pilgrims stayed for three days and suffered from water shortage, hundreds of thousands of Muslims were provided with water they needed (h. 1301 / 1883-1884). ${ }^{47}$

\subsection{Education-Training and Culture}

The studies carried out in order to make modern education common place in Ottoman State continued as usual at the time of Abdülhamid II. Increase in the number of schools contributed to state organization which was to be established in all provinces through the pervasive influence of the government. Education policy of Abdülhamid II, as in all other fields, was to integrate important elements of the Tanzimat program with other elements of the state that come from Islam and Ottoman convention. ${ }^{48}$ Accordingly, every effort was made for the education to be institutionalized in a modern fashion. In 1982, provincial directorate of education was established in 25 provinces. It is said that until 1898, directorates of education were founded in all provinces except for Hijaz. ${ }^{49}$ However, in 1891, on condition that expected results were obtained from income and allocation of education, directorate of education would be set up in Hijaz, and Muallim-i Evvel Hacı Said Efendi, a teacher at Medina Junior High School (Mekteb-i Rüşdiye), would be appointed to the school as the director with the same amount of salary. ${ }^{50}$

In 1891-1892, there were 6 madrasahs, 1 rüssdiye (junior high school), 43 sibyan mektebi (primary schools) and 2 libraries in Mecca, ${ }^{51} 17$ madrasahs, 1 rüşdiye, 11 sibyan mektebi, 12 libraries in Medina ${ }^{52}$ and 1 rüşdiye and 1 sibyan mektebi in Jidda. ${ }^{53}$ In the following years, an Idadi (High school) was opened in Anberiye district, Medina thanks to the initiative of Sheikh al-Haram Osman Ferid Pasha. ${ }^{54}$ By 1905-1906 academic year, there were 3 boys primary schools and 1 girls primary school in Hijaz, which had modern education system. In 1906-1907 academic year, there were 3 junior high schools, one of them in Mecca and two of them in Medina. Also, there were four private Junior High Schools; one of them in Medina and three of them in Mecca. ${ }^{55}$ By the year 1886, the number of students attending primary schools in Mecca was about $1150 .{ }^{56}$ The girls school built in Mecca by the order of Sultan Abdülhamid II, is really remarkable in that it showed how important it was for him to educate girls. This gorgeous four storey school building is still in place. ${ }^{57}$ Yet, it is obvious that these new schools were not well established in Hijaz province. Osman Nuri Pasha stated that the majority of the students

\footnotetext{
${ }^{46}$ BOA, Dahiliye Nezareti Mektubi Kalemi (DH.MKT), Dosya No: 841, Gömlek No: 6, Tarih: 5 Şaban 1323 (5 Ekim 1905); Irade Hususi (İ.HUS), Dosya No: 143 Gömlek No: 1324Ca/84, Tarih: 23 Cemaziyelevvel 1324 (15 Temmuz 1906); Angelo Pesce, Jiddah Portrait of an Arabian City, Oasis Publishing, 1977, p. 137.

${ }^{47}$ M. E. el-Mekkî, op. cit., p. 13.

48 Benjamin C. Fortna, Mekteb-i Hümayûn Osmanlı Imparatorluğu'nun Son Döneminde İslâm, Devlet ve Eğitim, Çeviren: Pelin Siral, İletişim Yayınları, İstanbul 2005, pp. 147, 218.

${ }^{49}$ See Bayram Kodaman, Abdülhamid Devri Eğitim Sistemi, TTK Yayınları, Ankara 1999, pp. 38-40.

${ }^{50}$ BOA, I..DH, 1218/95384, Tarih: 9 Recep 1308 (18 Şubat 1891).

${ }^{51}$ Hicaz Vilayeti Salnamesi, h. 1309 (1891-1892), pp. 184-185.

${ }^{52}$ Hicaz Vilayeti Salnamesi, h.1309 (1891-1892), p. 240.

${ }^{53}$ Hicaz Vilayeti Salnamesi, h. 1309 (1891-1892), pp. 274-275.

${ }^{54}$ M. E. el-Mekkî, op. cit., p. 10.

${ }^{55}$ Kodaman, op. cit., pp. 89, 104.

${ }^{56}$ Hicaz Vilayeti Salnamesi, h. 1303 (1885-1886), p. 196.

${ }^{57}$ Abdülhamid Kayıhan Osmanoğlu, Dedem Abdülhamid Hân, Yediveren Yayınları, İstanbul 2016, p. 70.
} 
attending Ottoman Junior High Schools were the children of civil servants or Turks, and that the number of Arab students was very low. ${ }^{58}$

Far away from the centre of Ottoman State, Arabia was a region where traditional life style was preserved to a large extent. This caused serious problems for the reforms to be introduced. Moreover, it was necessary to inform people of the region about the increasing influence of the English in Arabia. To this end, it was decided that a clan school should be opened in İstanbul to educate the children who were transferred from distant provinces. The first students of this school were the children of Arab Sheiks and the establishment. ${ }^{59}$ The clan school also transferred students from Hijaz. There were officers accompanying the Arab students studying here, and a certain amount of subsistence was also given to them by the state. $^{60}$

The state also took care of the education of Bedouin children in the Hijaz province. The works carried out regarding this issue was one of the reforms, which was especially in the form of religious education and training, needed in the Hijaz province. Fukaha ${ }^{61}$ were commissioned to give religious information to those in the suburbs and teach reading to children living in the desert. It was also requested that the salaries of the fukaha be paid on a regular basis. For a period of time, the governor of the province ordered a mobile officer to be appointed as inspector called as müfettiş-i fukaha, who would work for 1.000 kurush salary for inspecting the fukaha in question. However, the government stated that there was no money for the salary to be paid to this inspector, and that no such inspector was required for such work. In addition, it was asked to be careful when selecting the qualified people and to inspect whether they were doing their duty well or not. ${ }^{62}$

Another important initiative to support and develop educational and cultural activities in Hijaz is the establishment of a printing press in Mecca. The establishment of the Hijaz printing house took place in 1883, although establishment of a printing press in Hijaz was a request of the Shafii Mufti of Medina Seyyid Cafer Berzenci in $1874 .{ }^{63}$ The printing house (Matbaa-i Vilayet) was built opposite the government office by the Governor Osman Nuri Pasha on a state-owned plot in Mecca. Matbaa-i Vilayet was a modern, two-storey stone building. Letters in Arabic, Turkish, Persian, Hindi and Java languages were available in the printing house. There were three machines. All kinds of religious books and other works were printed and sent to the towns of Islam. ${ }^{64}$ In addition to this, the works coming into the Hijaz from anywhere else, were also examined in this printing house. ${ }^{65}$

\subsection{Communication and Transportation}

\subsubsection{Communication}

The works for telegraph communication in Hijaz came up with result at the time of Abdülhamid II. Suakin telegraph cable was extended from Jidda to Mecca and Taif, and new telegraph lines were installed. ${ }^{66}$ In addition, the telegraph line extending from Damascus to

\footnotetext{
${ }^{58}$ BOA, Yıldız Esas Evrakı (Y.EE), Dosya No: 8, Gömlek No: 18, Tarih: 5 Temmuz 1301 (17 Temmuz 1885).

${ }^{59}$ Selim Deringil, İktidarın Sembolleri ve İdeoloji II. Abdülhamid Dönemi (1876-1909), Çeviren: Gül Çağalı Güven, Yap1 Kredi Yayınları, İstanbul 2007, p. 134; Eugene L. Rogan, II. Abdülhamid'in Aşiret Mektebi (1892-1907), Çeviren: Özkan Akpınar; Alişan Akpınar, Osmanlı Devleti'nde Aşiret Mektebi, Aşiret Mektep Devlet, Aram Yayıncılık, İstanbul 2001, b.a.

${ }^{60}$ BOA, DH.MKT, 107/71, Tarih: 29 Muharrem 1311 (12 Ağustos 1893).

${ }^{61}$ Teachers familiar with religious knowledge.

62 BOA, DH.MKT, 1445/114, Tarih: 22 Zilhicce 1304 (11 Eylül 1887); DH.MKT, 1467/8, Tarih: 15 Rebiulevvel 1305 (1 Aralık 1887); DH.MKT, 1481/21, Tarih: 15 Cemaziyelevvel 1305 (29 Ocak 1888).

63 Dayl bin Ali el-Halidî, el-İdaretü'l-Osmaniyye ve Enzimetuha fi'l-Hicaz fi Ahdi's-Sultan Abdülhamid es-Sanî (h 1293-1327 / 1876-1909), Dareh el-Melik Abdülaziz, Riyad h. 1435 / m. 2014, p. 369.

${ }^{64}$ M. E. el-Mekkî, op. cit., pp. 14-15.

${ }^{65}$ BOA, DH.MKT, 1422/71, Tarih: 2 Ramazan 1304 (25 May1s 1887).

${ }^{66}$ M. E. el-Mekkî, op. cit., p. 15.
} 
Medina was completed. ${ }^{67}$ This line was planned to be extended from Jerusalem to Medina via Maan, Tabuk and Hadiyya, and from there to Mecca, so that the telegraph communication could also be done through land. ${ }^{68}$ For the telegraph line to be extended from Maan to Mecca, 560.000 kurush was granted. ${ }^{69}$ Again for the purpose of communication, a two-storey post and telegraph office was built opposite the government building in Mecca. ${ }^{70}$ It should be noted that the construction of the Hijaz telegraph line was carried out under very difficult conditions. Aside from the difficulties arising from the climate, the telegraph line workers were threatened by the Bedouin tribes, and the lines were destroyed from time to time during the construction. ${ }^{71}$ It is even mentioned that the sheriff instigated the Bedouins to burn the telegraph poles and cut the telegraph wires. ${ }^{72}$

\subsubsection{Transportation: Hamidiye-Hijaz Railway}

First of all, the main cities in Hijaz were connected by roads. People used to use these roads for their religious, commercial and other travels. ${ }^{73}$ We would like to give information about the Hijaz Railway, which is the most famous among the investments made for Hijaz, without going into the details of land transportation. It was stated that the Hamidiye-Hijaz Railway was built to facilitate journeys for pilgrimage. Thanks to this railway, transportation between Istanbul and Hijaz would be significantly accelerated. ${ }^{74}$ The project had political, economic and military objectives as well as its religious goal. Hijaz Railway would be connected to Medina and Mecca through Damascus, and with the help of a branch line extended to Jeddah, the pilgrims, who used seaway, would be transported to Mecca more easily. ${ }^{75}$ Many religious, political, economic, industrial, cultural and civilian benefits were expected from the railway for the places on the route besides Hijaz. ${ }^{76}$ Moreover, the Hijaz Railway would not end in Mecca; it would be extended to Yemen. In the long run, the railway line was planned to be extended through Central Arabia to Baghdad and Basra. ${ }^{77}$ The most ambitious side of the project was that the line would be built and operated entirely by the Ottoman State. Foreign capital would not be used in railway construction, the Hijaz line would be built by Muslim engineers, Muslims would work in construction, domestic materials would be used, and the holy railway line would be the work of Muslims in every way. ${ }^{78}$ Since the railways in the Ottoman Empire were constructed with the privileges provided to foreign companies, ${ }^{79}$ all these were serious targets.

Hijaz Railway, in other words the holy line, was one of the most important milestones of the Arabian policy, which Abdülhamid II was trying to implement under extremely hard conditions. Caliph-Sultan wanted to strengthen the position of religious leadership in the eyes of Ottoman Muslims and Muslims of the world by achieving this ideal. As a matter of fact, the Hijaz Railway project, which was welcomed with great enthusiasm in the Islamic world, took

\footnotetext{
${ }^{67}$ M. E. el-Mekkî, op. cit., p. 17.

${ }^{68}$ BOA, Yıldız Sadaret Hususi Maruzat Evrakı (Y.A.HUS), Dosya No: 363, Gömlek No:147, Tarih: 26 Recep 1314 (31 Aralık 1896).

69 M. E. el-Mekkî, op. cit., p. 11.

${ }^{70}$ M. E. el-Mekkî, op. cit., p. 15.

${ }^{71}$ BOA, Yıldız Mütenevvi Maruzat Evrakl, (Y.MTV), Dosya No: 242, Gömlek No: 48, Tarih: 26 Mart 1319 (8 Nisan 1903).

72 İbrahim Rifat Paşa, op. cit., v. 1, pp. 381-382.

${ }^{73}$ D. b. A. el-Halidî, op. cit., p. 412.

${ }^{74}$ Hicaz Demiryolu Layihası, Dersaadet, 1324, p. 1.

${ }^{75}$ Ufuk Gülsoy, Kutsal Proje Ortadoğu'da Osmanlı Demiryollarl, Timaş Yayınları, İstanbul 2010, pp. 69-77.

${ }^{76}$ Muhammed Arif, Kitabü's-Saadeti'n-Nâmiyeti'l-Ebediyyeti fi's-Sikketi'l-Hicaziyyeti'l- Hadidiyye, İÜ Ktp., AY, Nr. 4790, pp. 98-105.

${ }^{77}$ Ufuk Gülsoy, Hicaz Demiryolu, Eren Yayınc1lı, İstanbul 1994, p. 29.

${ }^{78}$ Murat Özyüksel, “Hicaz Demiryolu”, Türkler, Volume: 14, Editör: Hasan Celâl Güzel, Kemal Çiçek, Salim Koca, Yeni Türkiye Yayınları, Ankara 2002, p. 470.

79 Jacob M. Landau, The Hejaz Railway and the Muslim Pilgrimage A Case of Ottoman Political Propaganda, Wayne State University Press, Detroit 1971, p. 10.
} 
place in the Ottoman, Indian, Egyptian and other countries' press, and the believers were called to help the caliph with the railway project. The interest in the project was great, insomuch that Abdülhamid II was over supported by the Islamic world and increased his dignity as much as he could. The author of the journal Die Katholischen Missionen summed up the current situation with the sentence "...became the most popular man of all the Islamic world and the hero of the day at a stroke." ${ }^{\prime 80}$ In the local press, the returns of the project were described with great enthusiasm, and the Hijaz Railway was capturing first page news in the newspapers. ${ }^{81}$ Being considered as the symbol of stance against European sovereignty and influence, it was one of the important factors that increased the reputation of the project. ${ }^{82}$

Sultan Abdülhamid II issued the order to start the construction of the Hijaz Railway by declaring an ordinance on May 2, 1900. Construction began with an official ceremony on September 1, 1900. In the constructional works organized by an organization called Komisyon- $l$ Âli (Supreme Commission), foreign engineers were employed previously, but the number of European engineers decreased as construction progressed. Labor force consisted largely of the soldiers. After Madain Saleh (1906), all construction work was carried out by Muslim engineers, technicians and workers. The finance required for the works came from the Ziraat Bank loan, donations and other sources, while the railway materials were brought from Europe. In addition, there were also passenger wagons constructed in Tersane-i Âmire. The railway, which reached Medina in 1908, was inaugurated with an official ceremony on September 1, 1908. There were many large and small stations on the Hijaz Railway route. As the prayer times during the journey were taken into account, Masjid wagon was allocated to the trains and a muezzin was inducted. ${ }^{83}$ The Hamidiye-Hicaz Railway had the interest and economic support of almost all the Muslims of the world, especially India, Egypt, Russia and Morocco. ${ }^{84}$

There were many reasons why the Hijaz Railway was necessary. One of them was that the maritime route through the Suez Canal to the Hijaz was under the control of the British because of the British occupation in Egypt. ${ }^{85}$ It was necessary to build this railway to be able to dispatch troops from the centre of the Caliphate to the Hijaz in case of any enemy attack. ${ }^{86}$ The Hijaz and Baghdad railway constructions were against the British interests. The Hijaz Railway line passed near the Sinai Peninsula and the port of Aqaba. For England, this meant a threat to British presence in Egypt in the event of any military action. As a matter of fact, there was a tension that could turn into an armed conflict because the Sinai border was set in 1906. Signing a contract regarding the construction of Baghdad railway line with the Germans was regarded as a threat to India in the future. ${ }^{87}$ For all these reasons, the developments in the progress of the Hijaz Railway were closely followed by the Europeans. Alois Musil, who took long trips across the Arabian geography, stated the Turkish government's commitment to the completion of the

\footnotetext{
${ }^{80}$ Murat Özyüksel, Hicaz Demiryolu, Tarih Vakfi Yurt Yayınları, İstanbul 2000, p. 263.

81 "Hicaz Şimendifer Hattı", İkdam, Numara: 2094, 1 Muharrem 1318 (30 Nisan 1900), p. 1.

${ }^{82}$ William Ochsenwald, The Hijaz Railroad, The University Press of Virginia, USA 1980, p. 1.

${ }^{83}$ Ufuk Gülsoy, "Gerçekleşen Bir Rüya: Hicaz Demiryolu”, Osmanlı, Volume: 3, Editör: Güler Eren, Yayın Kurulu Başkanı: Halil İnalcık, Yeni Türkiye Yayınları, Ankara 1999, pp. 679-681.

${ }^{84}$ BOA, Yıldız Perakende Evrakı Elçilik Şehbenderlik ve Ateşemiliterlik (Y.PRK.EŞA), Dosya No: 37, Gömlek No: 90, Tarih: 1318 (1900-1901); Y.PRK.EŞA, 36/94, Tarih: 24 Teşrinievvel 1316 (7 Kasım 1900); Y.A.HUS, 441/48, Tarih: 6 Zilkade 1320 (4 Şubat 1903); Y.A.HUS, 525/22, Tarih: 23 Şaban 1326 (20 Eylül 1908); ayrıca See Gülsoy, Hicaz Demiryolu, pp. 74-85. By the way, the fact that the aid by Theodore Herzl for Hamidiye-Hijaz Railway was turned down is a notable reaction. Abdulhamid II ordered that the cheque of 200 liras given by Herzl for the construction of the railway be returned and that a paper which indicates that the cheque was returned be taken, and the order was carried out: BOA, Y.MTV, 228/30, Tarih: 5 Muharrem 1320 (14 Nisan 1902).

${ }^{85}$ BOA, Yıldız Perakende Evrakı Askeri Maruzat (Y.PRK.ASK), Dosya No: 88, Gömlek No: 41, Tarih: 26 Recep 1310 (13 Subat 1893).

${ }^{86}$ BOA, I.DH, 1434/1323Ra-17, Tarih: 19 Rebiulevvel 1323 (24 May1s 1905).

${ }^{87}$ Orhan Koloğlu, "Thomas Edward Lawrence”, Kutsal Topraklarda Casuslar Savaşı, İrfan Yayımcılık, İstanbul 1995, pp. 158-159.
} 
line, and pointed out the plan about the construction of the railway between Medina and Mecca towards the spring of $1908{ }^{88}$

In September, 1908 the length of Hijaz railway together with Haifa branch was 1.464 kilometres, and it cost more than 3.000.000 liras. ${ }^{89}$ The journey time was comparatively shorter. In earlier times, it took forty days to cover the distance between Damascus and Medina by camels, but now it took only 72 hours by the railway. ${ }^{90}$ The sale of the land around the Hamidiye-Hijaz Railway line to non-Muslims and foreigners, whether they are Ottoman subjects or not, was prohibited, and it was said that close attention must be paid to this issue. ${ }^{91}$ No one other than the Muslim subjects around the railway line was allowed to open or operate mines, do agricultural activities or inhabit by the Sultan. In order to prohibit such activities, Şura-yı Devlet (Council of State) was asked to prepare a law draft urgently, which was to be submitted by Meclis-i Vükelâ (Deputies Assembly) with an official report. ${ }^{92}$ Muslim immigrants were preferred to be placed on Hamidiye-Hijaz Railway route politically. ${ }^{93}$ On the other hand, in order for the line not to reach the holy land, the attacks of the Bedouin emerged as an important problem, and the measures to be taken in this regard were the subject of correspondences. $^{94}$

Because of the opposition of the Bedouin tribes, ${ }^{95}$ the construction of the HamidiyeHijaz Railway line was maintained under the protection of military units. While the construction was going on, it was ordered that military officers and soldiers from the armies, other than the 1st and 2nd Army, must be selected sent immediately to the regiment to be established to protect the line. ${ }^{96}$ During the construction of Medina-Mecca and Jeddah-Mecca lines of the Hijaz Railway, severe resistance of the emirs of Mecca and the Bedouins were encountered, and completion of the line was blocked. The reason behind this was clear. The Bedouins rented camels to the pilgrims, supplied food, drinks and other needs for them, whereby they earned a certain amount of income. In addition, the Bedouins were paid by the state under the name of "urban surresi" not to attack the caravans of pilgrims. The tribes were afraid of losing all these sources of income in the event that the railway reached the territory they lived. In addition to economic reasons, the Bedouins were also aware of the fact that the Hijaz Railway would strengthen dominance of the Ottoman state in the region. The new situation could put an end to the unamenable lifestyle they were accustomed to. The Mecca emirs also supported the Bedouins under the counter. Because, if the central authority gained power in the Hijaz it would influence emirs most, and they would take a serious blow to their political influence in the region. ${ }^{97}$ As a result, the Hijaz Railway would enable the Ottoman government to establish more control over the Makkah sheriffs. ${ }^{98}$

İbrahim Rifat Pasha, h.1325 (1907-1908) on his way to Medina after the pilgrimage, witnessed the speeches of Arab sheikhs among themselves. Allegedly he said that the sheriff told the sheikhs that the extension of the railway to the Hijaz would make the Germans come to

\footnotetext{
${ }^{88}$ Alois Musil, Arabia Deserta: A Topographical Itinerary, Published under the Patronage of the Czech Academy of Sciences and Arts and of Charles R. Crane, New York 1927, p. 53.

${ }^{89}$ See Gülsoy, Hicaz Demiryolu, p. 138.

${ }^{90}$ Gülsoy, Hicaz Demiryolu, p. 142.

${ }^{91}$ BOA, Meclis-i Vükela Mazbataları (MV), Dosya No: 118, Gömlek No:99, Tarih: 28 Rebiulevvel 1326 (30 Nisan 1908).

${ }^{92}$ BOA, I.DH, 1434/1323Ra-17, Tarih: 19 Rebiulevvel 1323 (24 May1s 1905).

93 BOA, Sadaret Mektubi Mühimme Kalemi Evrakı (A.MKT.MHM), Dosya No: 530, Gömlek No: 36, Tarih: 4 Cemaziyelevvel 1325 (15 Haziran 1907).

${ }^{94}$ BOA, DH.MKT, 1226/70, Tarih: 17 Kanunisani 1323 (30 Ocak 1908).

${ }^{95}$ A. Musil, op. cit., p. 53.

${ }_{96}^{96}$ BOA, Y.PRK.ASK, 258/36, Tarih: 24 Cemaziyelevvel 1326 (24 Haziran 1908); O. Koloğlu, a.g.b., p. 159.

${ }^{97}$ See M. Özyüksel, op. cit., pp. 475-476.

${ }^{98}$ Albert Hourani, Arap Halkları Tarihi, Çeviren: Yavuz Alogan, Hazırlayan: Tanıl Bora, İletişim Yayınları, İstanbul 2007, p. 332.
} 
these areas. Therefore, they would no longer transport the pilgrims and their belongings, so they would suffer economically. Moreover, this development would cause the freedom to spread among people. So a master and a slave would sit side by side and address each other as if they were equal. The bondwoman would have the same position with her master in his home. Arabs were not expected to welcome such behaviour because slaves were doing their external works, and houseworks were done by bondwomen. When there was equality, their orders would not be followed any longer. ${ }^{99}$ As it is seen, the concern that the Bedouins would suffer from social and economic loss in the short run because of the railway line led them to oppose to it. However, the world was undergoing a rapid change and how long they could resist. The innovations could bring new chances for them. But all of these were ideas unfamiliar to the Bedouins at that time, and they were going to exhaust the Ottoman State with their stance against the railway.

The British spy Arthur Wavell made a journey from Damascus to Medina by train only when the Hijaz Railway was put into service. Observing developments around the route while traveling, Wavell mentioned a rebellion initiated by the Bedouins at that time, and stated that the tribe of Beni Ali had declared a kind of holy war against the Turks, and, because of this, they called on all Arabs to help. He stated that the Bedouins declared that pilgrims would not be harmed, that the pilgrims were free to come and go, and that their fights were only with the government. Wavell stated that the requested support came in a short span of time, and that the Arab tribes came together for the first time with such an agreement. ${ }^{100}$ Tahsin Pasha also stated that some of the Arab tribes on the railroad were said, as they experienced in the completion of telegraph lines, "Because of these lines, you will deteriorate your old customs and traditions, and you will be deprived of the income allocated for you from the treasure, the voyages that you perform with camels and horses won't work, and the caravan trades will be removed." Arab sheikhs were repeatedly prompted by slush funds, gifts and weapons to be against the construction. Thereupon, military measures were taken by the Ottoman government, and the tribal sheikhs were treated with kindness and given advice. ${ }^{101}$

While the Bedouins reacted to the Hamidiye-Hijaz Railway, the people of Medina showed great interest in the construction of the line. ${ }^{102}$ Undoubtedly, the inhabitants of cities were more aware of the contribution of the modernization of means of transportation to the development and improvement of a place. It is worth mentioning that the information about the Bedouin uprisings given above by Wavell is somewhat exaggerated. It is clear that the British preferred to convey a small opposition movement against the Turks in an exaggerated way to the public. Therefore, no wonder the British, who made serious plans on the future of Arabia, would be pleased with any conflict here. However, what is at issue is the presence and relations of Wavell and others like him in Arabia, which must be questioned. In any case, all these thing indicate that the great investment of the Ottoman Empire in Haramayn took place under very difficult conditions. Despite all the difficulties, from Sultan Abdülhamid II and the bureaucrats, who carried out the task in the project, to the soldiers, thanks to the efforts of each individual, the Hijaz Railway reached Medina. Compared to the past, considering the advantages of pilgrimage by train, it would be better understood how committed and devoted the Ottomans were to facilitate the making of the pilgrimage, and how great a service they were doing for Muslims under those circumstances.

\section{Security}

Sultan Abdülhamid II, was closely interested in the security of Hijaz and strived to improve land and sea power facilities in the province as much as possible. Since he considered

\footnotetext{
${ }^{99}$ İbrahim Rifat Paşa, op. cit., v. 1, pp. 381-382.

${ }^{100}$ A. J. B. Wavell, A Modern Pilgrim in Mecca and a Siege in Sanaa, Hazell, Watson and Viney, Ld. Constable, London and Aylesbury, pp. 62-63.

${ }^{101}$ Tahsin Paşa'nın Yıldız Hatıraları Sultan Abdülhamid, Boğaziçi Yayınları, İstanbul 1999, pp. 349-350.

102 BOA, Y.PRK.ASK 251/8, Tarih: 28 Eylül 1323 (11 Ekim 1907).
} 
protection of security in Haramayn to be exceptionally important, he gave particular instructions to the commanders of military division, and stated specifically what to do about security and defence. ${ }^{103}$ There were usually around 6,000 troops in the Hijaz province, and the number of troops was rarely seen to be around 8.000. ${ }^{104}$ Since the young in Hijaz were exempted from military service, the security of the region was provided by Turks to a large extent. ${ }^{105}$ The military units in the Hijaz province were attached to the Seventh Army, ${ }^{106}$ and they were called the Hicaz Firka-i Müstekille-i Askeriyesi. Hijaz Military Division consisted of Infantry $64^{\text {th }}$ Regiment, Infantry $65^{\text {th }}$ Medine-i Münevvere Regiment, and Infantry $66^{\text {th }}$ Regiment. Apart from these regiments, The Hijaz had military units such as Artillery battalions, Castle divisions, commanders and soldiers at the service of the Emirate, Zabtieh Regiment, Infantry and Cavalry battalions and Bişe battalion. ${ }^{107}$ The number of military units in the province, their weapons, ammunition and other conditions were reported in detail to the Sublime Porte. ${ }^{108}$ After 1880s, the military force in the Hijaz was significantly increased by creating new security units compared to the past. ${ }^{109}$

As the famous Ottoman fortress named Ecyad (Ciyad), which was built in Mecca, overlooking the city, during the reign of Sultan Abdülhamid I (1781-1783) ${ }^{110}$ was ruined by time, it was pulled down, and a larger one was built at the same place by Osman Pasha. The castle, which was built to accommodate an infantry battalion and 300 soldiers, had wards, armoury and a store for artillery soldiers. ${ }^{111}$ Castle Ecyad, with its magnificent stance seen from the Masjid al-Haram, was the most notable one among the military symbols of the Ottoman Empire. ${ }^{112}$ During the reign of Sultan Abdülhamid II, new military buildings were constructed in Jeddah and other places, and the old ones were repaired and made more convenient. Among the new military investments in the Hijaz province, Kışla-i Hümayun, which had a capacity of 8,000 soldiers in Taif, attracts attention. ${ }^{113}$ Emir Şekib Arslan, who defined Taif as the military base of the Ottoman Empire in the Arabian Peninsula because of the barracks, stated that there is a full-service hospital near the barracks and a mansion for military meetings in the middle of the barracks. He stated that the structure, which had a length of 300 meters and a width close to its length, is one of the biggest military barracks in the world. ${ }^{114}$

During the governorship of Osman Nuri Pasha (1882-1886), an outpost with a capacity of 40 soldiers in a central point in Mecca, and two barracks, one for the mobile artillery soldiers in the Ciyad district, were built. The barracks named Gayret, on the Mountain Hindi, was also reconstructed. ${ }^{115}$ The administrative structure of the sancak of Medina in the form of guardianship (muhafizlık), which was a high military position showed that, in a sense, the city was seen as a security centre in Hijaz. ${ }^{116}$ The town of Wajh, located on the north eastern shores

\footnotetext{
103 BOA, Y.EE 6/16, Tarih: 11 Cemaziyelevvel 1309 (13 Aralık 1891).

${ }^{104}$ Ochsenwald, Religion, Society and the State in Arabia, p. 154.

105 BOA, Y.EE 8/18/4, Tarih: 5 Temmuz 1301 (17 Temmuz 1885); David George Hogarth, Hejaz Before World War I A Handbook, The Oleander Press, Cambridge, 1978, p. 47; Ochsenwald, Religion, Society and the State in Arabia, p. 154.

${ }^{106}$ Hicaz Vilayeti Salnamesi, h. 1305 (1887-1888), p. 123.

${ }^{107}$ Hicaz Vilayeti Salnamesi, h. 1309 (1891-1892), pp. 159-182.

${ }^{108}$ BOA, Y.PRK.ASK 44/74, Tarih: 29 Cemaziyelahir 1305 (13 Mart 1888).

109 BOA, Yıldız Sadaret Resmi Maruzat Evrakı (Y.A.RES), Dosya No: 14, Gömlek No: 34, Tarih: 23 Şaban 1298 (21 Temmuz 1881); Z. Kurşun, op. cit., v. 1, p. 322.

${ }^{110}$ Mustafa Sabri Küçükaşcı, "Mekke" (Osmanlı Dönemi), Türkiye Diyanet Vakfi İslâm Ansiklopedisi, Volume: 28, Türkiye Diyanet Vakfi, Ankara 2003, p. 566.

${ }^{111}$ M. E. el-Mekkî, op. cit., p. 15.

112 See photo, İlmiye Salnamesi, Matbaa-i Âmire, Daru'l-Hilafeti’l-Aliyye h. 1334 (1915-1916), pp. 18-19.

${ }^{113}$ M. E. el-Mekkî, op. cit., pp. 15-16.

${ }^{114}$ E. Ş. Arslan, op. cit., p. 317.

${ }_{115}$ M. E. el-Mekkî, op. cit., p. 15.

${ }^{116}$ Salname-i Devlet-i Aliyye-i Osmaniye, Âlem Matbaası, Dersaadet h. 1315 (1897/1898), pp. 342-343; Satı el-Husrî, el-Biladu'l-Arabiyye ve'd-Devletü'l-Osmaniyye, Daru'l-i̇lm li'l-Melayin, Beyrut 1960, p. 241.
} 
of the Red Sea, which was ruled by kaymakam (lieutenant colonel) with the rank of muhafiz, was now being used as a strategic military base. ${ }^{117}$ As of 1901 , Wajh, which had 50 infantry soldiers equipped with heavy weapons, became an important defence point for the Hijaz. ${ }^{118}$ For the protection of the coasts of the Hijaz and Yemen, an agency was established on certain wharfs as in al-Luhayya. ${ }^{119}$

In 1886, especially for the safety of the northern shores of the Hijaz province, a small ship in the port of Jeddah was asked to be sailed along the shore once in fifteen days. ${ }^{120}$ Sultan Abdülhamid II gave importance to the protection of the coasts of the seas, especially. The Sultan also demanded that strong fleet be established for the protection of the Hijaz coast, and small and inexpensive ships with private design, which are economical to operate, which could be used for patrolling purposes on the coasts of the Red Sea and the Gulf of Basra were ordered from Europe. ${ }^{121}$ The Ottoman navy in the Hijaz was called Bahr-i Ahmer Komodorluğu. In 1892, there were 3 corvettes, 1 gunboat and 1 ship in the Hijaz fleet. At the beginning of the 1890s, Kaymakam Sabri Bey was known as the commodore of Bahr-i Ahmer Komodorluğu Delegation. ${ }^{122}$

In spite of everything, it is understood that the Ottoman State had difficulty in protecting the coastal security in the Hijaz. Indeed, the fact that Ottoman ships in the port of Jeddah were not good enough for the Red Sea coasts caused a serious problem in pursuing the sea bandits. For this reason, more useful ships were sometimes requested from Istanbul for Hijaz, but a few newly sent ships were far from meeting their needs in the strictest sense. ${ }^{123}$

\section{Religious Services and Charities}

\subsection{Mecca}

Sultan Abdülhamid II has carried out a number of activities that can be seen as a manifestation of the idea of the Islamic unity, and wanted to take an attitude worthy of caliphate with the sensitivity of religious elements belonging to Muslims. ${ }^{124}$ Many religious or social benefactions of the Sultan Abdülhamid II reached the most remote places of the Ottoman lands. In terms of geographical dispersion, Istanbul and Hijaz have importance among the Sultan's benefactions. Namely, $41 \%$ of the expenditure in this item was made to Istanbul and $24 \%$ to Hijaz province. In other words, when Istanbul is excluded, Hijaz ranks first in the favours of the Sultan. It is possible to think of the expenditures made for Hijaz as a continuation of the Ottoman tradition. However, this generous attitude of Abdülhamid II towards the Hijaz province is also closely related to the political conjuncture of the period. Hospital, charities like watercourses and guest house can be primarily considered as an extension of Abdülhamid's caliphate politics. Every service provided for Haramayn was intended to show the authority of the Ottoman State, and its influence on the region to the crowded Muslim groups gathered in Hijaz every year for Hajj. The efforts of the British to erode the legitimacy of the Ottoman Caliphate must have affected the importance Abdülhamid II attached to the province of Hijaz.

\footnotetext{
${ }^{117}$ BOA, $M V$, 21/53, Tarih: 15 Şevval 1304 (7 Temmuz 1887).

${ }^{118}$ D. b. A. el-Halidî, op. cit., p. 191.

119 BOA, DH.MKT, 21/9, Tarih: 28 Şaban 1310 (17 Mart 1893).

${ }^{120}$ BOA, I.DH, 975/77007, Tarih: 27 Rebiulahir 1303 (2 Şubat 1886).

${ }_{121}^{12}$ BOA, Y.MTV, 65/117, Tarih: 25 Muharrem 1310 (19 Ağustos 1892); S. Deringil, op. cit., pp. 85-86.

${ }^{122}$ Hicaz Vilayeti Salnamesi, h. 1309 (1891-1892), pp. 268-272.

${ }^{123}$ BOA, Yıldız Perakende Evrakı Başkitabet Dairesi Maruzatı (Y.PRK.BŞK), Dosya No: 27, Gömlek No: 42, Tarih: 23 Muharrem 1310 (17 Ağustos 1892); Y.PRK.ASK 129/94, Tarih: 26 Safer 1316 (16 Temmuz 1898).

${ }^{124}$ Muhammed Harb, es-Sultan Abdülhamid es-Sâni Âhiru's-Selatini'l-Osmaniyyin el-Kibar, Daru'l-Kalem, Dımaşk (h. 1417/1996), p. 171.
} 
Therefore, it can be said that international politics played a decisive role in the internal costs of Abdülhamid II for the Hijaz province. ${ }^{125}$

Sultan Abdülhamid's guest house built for poor pilgrims in Mecca is one of the most prominent benefactors in Haramayn. ${ }^{126}$ The building, which was covered by the Sultan and bears the name of Misafirhane-i Hümayun, was constructed in a very large and sound manner. It was built on a state-owned land located in the mouth of the Hefayir Valley on the west of Mecca, on the road to Jeddah. ${ }^{127}$ This region, known as Cervel, ${ }^{128}$ is about half an hour from the Kaba (Kâbe). The guest house, which was built in a large area, had two floors. It was built with stone and had a size to accommodate 6.000 people. The construction of the building was started in January, 1894. The construction was started under the supervision of a commission chaired by Asaf Paşa, and then Miralay Münir Bey was appointed to replace him. A total size of 25.000 cubic meters was completed in June 1897. The annual cost of the guest house, which was completed by spending more than 50.000 liras, was 15.000 liras. ${ }^{129}$ A Nazir, a muawin, an imam, a muezzin and a janitor were sent here to see their needs. In the guest house, the poor pilgrims were given soup, pilaf with meat, bread and other meals every day. The Muslim world appreciated this service of Abdülhamid II as the Caliphate. ${ }^{130}$

In addition, there were many other charities in Hijaz. Just in the second year of Abdülhamid's reign (h. 1295-1878) the roof of the Kaba was furnished with marble slabs. ${ }^{131}$ In h. 1297 (1879-1880), some of the beams on the roof of the Kaba were renovated and some were repaired. When the construction was completed, a poem that praises Abdülhamid's service written by the Shafii Mufti of Mecca, Seyyid Ahmad Dahlan Efendi was written on the wall with a date under it. The two silver keys of the Kaba were built in Istanbul, the cover, the lock and the Silver Key of Makam-ı İbrahim were renewed, and the old cover was sent to Istanbul by Muhammed al-Emin Al-Makki, who was assigned for this task. The steps of Makam-1 İbrahim and Bab-ı İbrahim were repaired and the paint, embroidery and gildings were renewed. Seven great silver candleholders and numerous censers were given as a gift to be burned on the threshold to illuminate the Kaba. ${ }^{132}$

The floor of the Haram al-Sharif was repaired, and then it was painted. For the restoration of the six marble columns in the direction of the Davudiye madrasa, permission was requested by Hacı Osman Nuri Pasha, who was the governor and commander of Hijaz and Sheikh alHaram of Mecca at that time, and in accordance with the ordinance published in h. 1300 (1882-1883) these columns were repaired. Meanwhile, some of the domes in front of Bâblâli were renovated, and all the pavements under the dome were repaired. In the same year, the Governor Osman Nuri Paşa took the Hanbali Makam, located against al-Hajar al-Aswad (the Black Stone), to the level of Hanafi Makam, had the necessary places of the Haram al-Sharif repaired, and had the underside of the dome scented and adorned. ${ }^{133}$

The realms in Safa and Marwa were repaired, and the sand accumulated in the Vadi-i Ibrahim because of floods at various times, and the stones and sand accumulated up to The

\footnotetext{
${ }^{125}$ Nadir Özbek, Osmanlı Imparatorluğu'nda Sosyal Devlet Siyaset, İktidar ve Meşruiyet 1876 - 1914, İletişim Yayınları, İstanbul 2008, pp. 174-176, 186; Cezmi Eraslan, II. Abdülhamid ve İslam Birliği, Ötüken Neşriyat A.Ş., İstanbul 2019, pp. 263-267.

${ }^{126}$ BOA, Y.A.HUS 391/114, Tarih: 20 Recep 1316 (4 Aral1k 1898).

${ }^{127}$ M. E. el-Mekkî, op. cit., p. 14.

${ }^{128}$ See Belgelerle Osmanlı Devrinde Hicaz, Volume: 1, Editör: Ömer Faruk Yılmaz, Hazırlayanlar: İlhan Ovalığlu, Raşit Gündoğdu at al., Çamlıca Basım Yayın, İstanbul 2008, p. 352.

${ }^{129}$ See Gülden Sarıyıldız, "II. Abdülhamid'in Fakir Hacılar İçin Mekke'de İnşa Ettirdiği Misafirhane", İÜ Edebiyat Fakültesi, Tarih Enstitüsü Dergisi, Issue: 14, 1994, pp. 127-145.

${ }^{130}$ M. E. el-Mekkî, op. cit., p. 14.

131 İbrahim Rifat Paşa, op. cit., v. 1, pp. 264-265.

${ }^{132}$ M. E. el-Mekkî, op. cit., pp. 6-7.

${ }^{133}$ M. E. el-Mekkî, op. cit., p. 7.
} 
Haram al-Sharif Gates were removed. Meanwhile, painting and embroidery of Makam-1 İbrahim and Zamzam well were renewed. ${ }^{134}$ The minbar of Haram al-Sharif was repaired by the master builders sent from Istanbul. In addition, Hicr-i Ismail and Tawaf ground marbles were renovated again. The two sanjaks hanged on both sides of the minbar of the Haram al-Sharif every Friday were renewed in Istanbul and sent to Mecca. H. 1301 (1883-1884) ${ }^{135}$

It was a routine practice to renew the cover of the Kaba and bring the old one to Istanbul and put it in the Hazine-i Hümayun when it was Hacc-ı Kebir. In the meantime, it was customary for the Emirate to grant money to those who were given the task of bringing the cover to İstanbul. ${ }^{136}$ In 1901, the ordinance to repair the madrasah, a the foundation of Sultan Suleyman Khan, adjacent to Mecca Haram al-Sharif, was published, ${ }^{137}$ started an initiative in 1908 upon a letter from Hijaz province to Istanbul for the renewal of al-Hajar al-Aswad envelope in the Kaba. ${ }^{138}$ In Mecca, various services were provided for the houses and mausoleums tomb of the important personalities who lived in the early periods of Islamic history. The tombs of Amina -mother of Prophet Muhammad- and Khadija -wife of Prophet Muhammad- located in Cennet-i Mualla were repaired and expanded. The sarcophaguses and their covers were sent from Istanbul and renewed. In addition, high quality carpets, curtains and silver candlesticks were given as presents for these tombs. These studies were conducted in $h$. 1295 (1878), during Ahmet 'Eta Efendi's Haram al-Sharif directorate, and precious plates were hung here by him. ${ }^{19}$ Today there are no tombs, therefore no items belonging to them; there are no grave stones or inscriptions to show who the graves belong to in the cemetery area of Cennet-i Mualla. There exist only concrete walls around the earth graves and headstones here and there indicating the exact locations of the graves.

In h. 1300 (1882-1883), the house where the Prophet Muhammad was born was repaired. The embroideries and paints of the house were completed, and high quality curtains made of green sateen were hung on the windows. The sarcophagus was renewed, and clothes on which the verses of the Qur'an were embroidered with silk was given as a gift. Moreover, the houses of the first four caliphs Abu Bakr, Omar, Uthman, Ali and the other prominent figures of Islam Khadija, Fatima, Hamza, Abbas, Umm Hani and Abu Sufyan, the masjid where one of the great companions of the Ashab, Bilal Habashi, recited ezan for the first time on the mount of Abu Kubeys, and the tombs and offices of Abdullah bin Abbas buried in Taif -the leader of commenters (müfessirs)- and Muhammad b. Hanefiye, who is the third son of Ali b. Abu Talib were repaired and the covers and curtains were given by Abdülhamid II as a gift (h. 1301/ 1883-1884). ${ }^{140}$ The paths to the cave, where Prophet Muhammad and his close companion Abu Bakr hid, on Mount Thawr were steep and rough. It was hard for the visitors and pilgrims to climb there. In h. 1306 (1888-1889), Ismail Hakki Pasha, governor of Hijaz, attempted to improve these roads, and the roads to the cave were fixed by Münir Pasha. ${ }^{141}$

\subsection{Medina}

In Medina, the maintenance of the domes, walls and gates of al-Haram an-Nabawi were performed primarily as a start of the works of reconstruction and furnishing. ${ }^{142}$ The dome pillars of Prophet Muhammad's tomb and the bridge between them were repaired by spending 75.380 kurush. Other parts of al Masjid an-Nabawi that needed to be repaired were also repaired. The

\footnotetext{
${ }^{134}$ M. E. el-Mekkî, op. cit., p. 9.

${ }^{135}$ M. E. el-Mekkî, op. cit., pp. 16-17.

${ }^{136}$ BOA, Ylldız Sadaret Resmi Maruzat Evrakı (Y.A.RES), Dosya No: 10, Gömlek No: 20, Tarih: 20 Rebiulahir 1298 (22 Mart 1881).

${ }^{137}$ BOA, Irade Evkaf (I.EV), Dosya No: 29, Gömlek No: 21 (1319B/10), Tarih: 26 Recep 1319 (8 Kasım 1901).

${ }^{138}$ BOA, Y.MTV, 312/176, Tarih: 22 Cemaziyelahir 1326 (22 Temmuz 1908).

${ }^{139}$ M. E. el-Mekkî, op. cit., p. 8.

${ }_{140}$ M. E. el-Mekkî, op. cit., pp. 8-9.

${ }^{141}$ M. E. el-Mekkî, op. cit., p. 13.

${ }^{142}$ BOA, I.EV, 13/42, (1313Z/15), Tarih: 18 Zilhicce 1313 (31 May1s 1896).
} 
dome of the tomb of the Prophet and the interior of the Haram al-Sharif were renewed using the lead, paint, embroidery and gildings. Numerous lamps were donated to Ravza-i Mutahhara, and the paint and gildings of the Ravza-i Mutahhara and Ebvab-i Saadet were renewed. For Medina Haram al-Sharif, lamps shaped like watermelon and silver candles of 38.404 cents were produced and sent. ${ }^{143}$ Moreover, coat of arms and things like that costing 63.225 kurush which were produced for important places in Medina, and oil lamps and silver candlesticks costing 25.144 kurush for Mecca were given. Besides these, many masjids and tombs in Medina and around it were repaired and provided with everything needed. Many Qur'ans were sent to Mecca and Medina. Highly precious carpets were woven at a factory in Hereke and sent in order to be laid in the Haram al-Sharif of Medina. In the Haram al-Sharif, 157 salaried people were employed to read Bukhari, Şifa, Ecza, Delâil, Ahzab and Salavat-i Sharif. The Şer'iyye court in Medina was restored. ${ }^{144}$ In addition, the Great Taif Masjid was broadened and renovated, and a school, a clock room and a public fountain were built as an extension. (H. 1294/1877-1878). ${ }^{145}$

The Hamidiye Mosque, built across from the railway station in Medina, is an Ottoman monument with its simple but eye-catching architecture. The foundation of the mosque was laid by Müşir Kazım Pasha at a ceremony attended by the Pilgrim Regiment. ${ }^{146}$ İbrahim Rifat Pasha stated that, while he was in Medina in February 1908, a hard work was done to complete the construction of the railway station and the mosque that started to be built near it. ${ }^{147}$ The mosque, planned as the one with a single dome, seven smaller domes, two of which are relatively larger than others. Five of the domes cover the narthex, and under them are five arches supporting them. The mosque was constructed of black stones and two minarets, each with a balcony, were placed on the Northeast and northwest corners. ${ }^{148}$ The mosque, which has a modest and elegant appearance, is located on a main street by the Haram al-Sharif. Hamidiye (Anberiye) Mosque is in service today. The mihrab of the mosque is made of stone, and there are two small round marble columns on both sides in the interior of it. There are two large windows on both sides of the mihrab, upper part of which has the niche stalactite (mukarnas), which is typical of Turkish mosques. In the interior of the dome made of cut stone, there is no decoration.

Sultan Abdülhamid II provided direct financial support to public investments in Hijaz. For example, he gave 30,000 liras for the construction costs of the guest house, the hospital and the quarantine station (tahaffuzhane), which he ordered to be built in Mecca and Jeddah. This assistance was published in the international press as favour (ihsan) made by the caliphate authority. ${ }^{149}$ It is understood that the Sultan did such assistance both for charity and to support the development of the province. However, allowing such issues to take place in international press reveals the political aspect of the behaviour. Considering that the European states generally have large Muslim colonial populations, Abdülhamid II, thanks to these publications, gave the message that he had fulfilled the requirements of his caliphate over Hijaz, and tried to increase his prestige and dignity in the entire Islamic world.

\section{Conclusion}

After the Tanzimat, Ottoman Empire started feverish innovative activities in many fields. Remarkable efforts were made in order to spread all the reforms and innovations across the whole empire, going beyond boundaries of İstanbul. Yet, it was not easy to some administrative or legal changes into practice in the provinces, such as Hijaz and Yemen, which were far away

\footnotetext{
${ }^{143}$ M. E. el-Mekkî, op. cit., p. 9.

${ }^{144}$ M. E. el-Mekkî, op. cit., pp. 9-10; BOA, Yıldız Perakende Evrakı Serkurenalık Evrakı (Y.PRK.SRN), Dosya No: 1, Gömlek No: 24, Tarih: 15 Muharrem 1297 (29 Aralık 1879).

${ }^{145}$ M. E. el-Mekkî, op. cit., p. 16.

${ }^{146}$ BOA, DH.MKT, 1223/9, h. 2 Zilhicce 1325 (6 Ocak 1908).

147 İbrahim Rifat Paşa, op. cit., v. 2, p. 209.

${ }^{148}$ Sabit Aydın, Osmanlı Döneminde Medine'de Yapılan Tarihi Eserler, Yayınlanmamış Yüksek Lisans Tezi, Erciyes Üniversitesi, Sosyal Bilimler Enstitüsü, Kayseri 2007, pp. 116-118.

${ }^{149}$ BOA, Y.A.HUS, 283/67, Tarih: 25 Rebiulahir 1311 (5 Kasım 1893).
} 
from the centre, and where traditional lifestyle was largely maintained. Until the reign of Sultan Abdülhamid II, the institutions of the state had made considerable progress in terms of modernization. Abdülhamid II also encouraged public investments so that the country could have a modern appearance in general, and followed a policy which drew attention with the operations and achievements related to the provinces. In this sense, Hijaz takes the lead among the provinces where the Sultan's investments are pretty remarkable. While most of the investments in Haramayn formerly centered on religious places, especially public investments were given priority in Abdülhamid's rule. Strict security measures were taken providing security forces with modern apparatus in Hijaz have been improved due to both the terrible memories that the Wahhabi threat had left in memories and possible external threats that might arise. However, religious places were not neglected, the issues and works regarding the religion were dealt with as usual.

In Hijaz, a substantial reform movement and renovation process were initiated with new constructions, starting with the government offices. The health care house, the hospital with fourty beds and the pharmacy, which were built in Mina, were urgent precautionary measures taken primarily the primarily for the health problems especially in the Hajj seasons, and other health investments and health care issues of the province were dealt with afterwards. The establishment of the Hijaz Medical Organization took place in 1895 during the reign of Abdülhamid II. As a result of the works carried out under the leadership of Osman Nuri Pasha, Ayn-1 Zübeyde watercourse was constructed in such a way that it could be used for many years. Water reservoirs and fountains were built in Makkah, and fountains with taps were placed around the Haram al-Sharif for pilgrims. In addition, water was provided for many public institutions. Osman Nuri Pasha, at the end of three and a half years of work, managed to bring water to Jeddah, which was used both in public institutions and elsewhere in the city. One of the most important investments made by the Ottoman State to solve water problem in Hijaz was the establishment of water distillation facilities in Jeddah and Yanbu in order to obtain drinking water by distilling sea water. Thanks to these facilities, a small contribution has been made to the drinking water of the cities.

In the second half of the $19^{\text {th }}$ century, schools providing modern education were opened in addition to the madrasas, which were classical educational institutions in Hijaz. During the reign of Abdülhamid II, there were a limited number of secondary school (rüssdiye) in the province besides many primary school (sıbyan mektebi). In addition, the opening of a high school (idadi) by Osman Ferid Paşa in Medina was an important development in terms of increasing the level of education. The four-storey girls school built in Mecca by the order of Sultan Abdülhamid II, is really remarkable in that it showed how important it was for him to educate girls. The Tribal School, which had students from Hijaz to increase the number of educated people in the province, is worth mentioning. There were a lot of libraries in Hijaz except for the schools. In addition, the establishment of the printing house, which was an indispensable tool of education and cultural activities in Mecca, was also at the time of Abdülhamid II. The printing press attained a place in the cultural activities in Hijaz and delivered important publishing services.

With the works done for telegraph communication in Hijaz, the region started to benefit from modern means of communication at a contemporary level. During the reign of Sultan Abdülhamid II, the Suakin telegraph cable was extended from Jeddah to Mecca and Taif, and the Damascus-Medina telegraph line was completed. It is possible to say that the Hijaz Railway, which was built to facilitate pilgrimage, was the largest investment in Hijaz. Besides the religious target of the Hijaz railway project, it also had political, economic and military targets. Through this railway, one would be able to travel to Medina and Mecca through Damascus. In the event of a war, the rapid deployment of troops to Hijaz was among the main targets. It was also hoped that Hijaz Railway would contribute to the development of Hijaz province. The project had ambitious aspects in that it relied on Islamic capital, and that the pipeline was 
construction by Muslim engineers, soldiers, using as much local material as possible. Hijaz railway, when it reached Medina in 1908, aroused a great echo in the world and because of the serious targets, it was seen many times as the most concrete product of Islamic unity of Abdülhamid II.

Sultan Abdülhamid II was extremely sensitive about the safety of Hijaz. In his years of reign, new military elements were added to Hijaz and efforts were made to improve the existing ones. In the province where the young people of Hijaz were exempted from military service, he served as a major military force, consisting of Turks. The Hijaz military units, called Hicaz Fırka-i Müstekille-i Askeriye, were attached to the Seventh Army. In Hijaz, there was a crowded military organization, including artillery battalions, fortress squads and security units at the service of the Emirate. After the 1880s, the military force in Hijaz was gradually increased. In Hijaz, there was also an Ottoman naval fleet named Bahr-i Ahmer Komodorluğu. Although there were no large and fast ships in the fleet, the naval units carried out a number of valuable activities for the coastal safety of the region.

During the reign of Abdülhamid II, the services to religious places were taken care of, and the deficiencies were resolved. Although large-scale changes were not made in al-Masjid alHaram, al-Masjid an-Nabawi and other religious elements, through various maintenance and renovation works, the decent and eye-catching views of religious environments were desired to be kept continuously. In Medina, The Hamidiye Mosque, built across from the Hijaz railway station as a religious monument during the reign of Abdülhamid II, has a special place with its modest style, which is open to worship today. One of the highlights of every activity carried out in Hijaz is that the Sultan made significant contributions to each investment. For Hijaz railway, telegraph line, guesthouse and all other services, the Sultan made significant contributions. Among the benefactions of Abdülhamid, who had bestowed his favours to the most remote corners of the Ottoman geography, the highest share after Istanbul belongs to Hijaz. Every service to the Haramayn can be considered to be a service to all Muslim peoples, especially because of the Hajj service. Generous attitude of Abdülhamid II towards the holy cities of Islam shows the level of awareness of the title he carries as Caliph-Sultan, and shows how much responsibility he has for the Muslim community.

\section{Bibliography}

\section{Archive Documents}

\section{Türkiye Cumhuriyeti Cumhurbaşkanlığı Devlet Arşivleri Başkanlığı Osmanlı Arşivi (BOA)}

Dahiliye Nezareti Mektubi Kalemi (DH.MKT): DH.MKT, 1422/71, Tarih: 2 Ramazan 1304 (25 Mayıs 1887); DH.MKT, 1445/114, Tarih: 22 Zilhicce 1304 (11 Eylül 1887); DH.MKT, 1467/8, Tarih: 15 Rebiulevvel 1305 (1 Aralık 1887); DH.MKT, 1481/21, Tarih: 15 Cemaziyelevvel 1305 (29 Ocak 1888); DH.MKT, 21/9, Tarih: 28 Şaban 1310 (17 Mart 1893); DH.MKT, 107/71, Tarih: 29 Muharrem 1311 (12 Ağustos 1893); DH.MKT, 841/6, Tarih: 5 Şaban 1323 (5 Ekim 1905); DH.MKT, 1223/9, h. 2 Zilhicce 1325 (6 Ocak 1908); DH.MKT, 1226/70, Tarih: 17 Kanunisani 1323 (30 Ocak 1908).

Irade Dahiliye (I.DH): I.DH, 800/64862, Tarih: 22 Rebiulevvel 1297 (4 Mart 1880); I.DH, 975/77007, Tarih: 27 Rebiulahir 1303 (2 Şubat 1886); I.DH, 1218/95384, Tarih: 9 Recep 1308 (18 Şubat 1891); I.DH, 1434/1323Ra-17, Tarih: 19 Rebiulevvel 1323 (24 May1s 1905).

Irade Evkaf (İ.EV): İ.EV, 13/42, (1313Z/15), Tarih: 18 Zilhicce 1313 (31 May1s 1896); I.EV, 29/21 (1319B/10), Tarih: 26 Recep 1319 (8 Kasim 1901). 
Irade Hususi (İ.HUS): I.HUS, 143/1324Ca/84, Tarih: 23 Cemaziyelevvel 1324 (15 Temmuz 1906).

Meclis-i Vükela Mazbataları (MV): MV, 21/53, Tarih: 15 Şevval 1304 (7 Temmuz 1887); MV, 118/99, Tarih: 28 Rebiulevvel 1326 (30 Nisan 1908).

Sadaret Mektubi Mühimme Kalemi Evraki (A.MKT.MHM): A.MKT.MHM, 530/36, Tarih: 4 Cemaziyelevvel 1325 (15 Haziran 1907).

Yıldız Esas Evrakı (Y.EE): Y.EE, 8/18, Tarih: 5 Temmuz 1301 (17 Temmuz 1885); Y.EE, 6/16, Tarih: 11 Cemaziyelevvel 1309 (13 Aralık 1891).

Yıldız Mütenevvi Maruzat Evrakl, (Y.MTV): Y.MTV, 65/117, Tarih: 25 Muharrem 1310 (19 Ağustos 1892); Y.MTV, 228/30, Tarih: 5 Muharrem 1320 (14 Nisan 1902); Y.MTV, 242/48, Tarih: 26 Mart 1319 (8 Nisan 1903); Y.MTV, 312/176, Tarih: 22 Cemaziyelahir 1326 (22 Temmuz 1908).

Ylldı Perakende Evrakı Askeri Maruzat (Y.PRK.ASK): Y.PRK.ASK 44/74, Tarih: 29 Cemaziyelahir 1305 (13 Mart 1888); Y.PRK.ASK, 88/41, Tarih: 26 Recep 1310 (13 Şubat 1893); Y.PRK.ASK 129/94, Tarih: 26 Safer 1316 (16 Temmuz 1898); Y.PRK.ASK 251/8, Tarih: 28 Eylül 1323 (11 Ekim 1907); Y.PRK.ASK, 258/36, Tarih: 24 Cemaziyelevvel 1326 (24 Haziran 1908).

Yıldız Perakende Evrakı Başkitabet Dairesi Maruzatı (Y.PRK.BŞK): Y.PRK.BŞK, 27/42, Tarih: 23 Muharrem 1310 (17 Ağustos 1892).

Yıldız Perakende Evrakı Elçilik Şehbenderlik ve Ateşemiliterlik (Y.PRK.EŞA): Y.PRK.EŞA, 36/94, Tarih: 24 Teşrinievvel 1316 (7 Kasım 1900); Y.PRK.EŞA, 37/90, Tarih: 1318 (1900-1901).

Yıldız Perakende Evrakı Serkurenallk Evrakı (Y.PRK.SRN): Y.PRK.SRN, 1/24, Tarih: 15 Muharrem 1297 (29 Aralık 1879).

Yıldız Sadaret Hususi Maruzat Evrakı (Y.A.HUS): Y.A.HUS, 283/67, Tarih: 25 Rebiulahir 1311 (5 Kasım 1893); Y.A.HUS, 363/147, Tarih: 26 Recep 1314 (31 Aralık 1896); Y.A.HUS 391/114, Tarih: 20 Recep 1316 (4 Aralık 1898); Y.A.HUS, 441/48, Tarih: 6 Zilkade 1320 (4 Şubat 1903); Y.A.HUS, 525/22, Tarih: 23 Şaban 1326 (20 Eylül 1908).

Yıldız Sadaret Resmi Maruzat Evrakı (Y.A.RES): Y.A.RES, 10/20, Tarih: 20 Rebiulahir 1298 (22 Mart 1881).

Yıldız Sadaret Resmi Maruzat Evrakı (Y.A.RES): Y.A.RES, 14/34, Tarih: 23 Şaban 1298 (21 Temmuz 1881).

\section{Yearbooks}

Hicaz Vilayeti Salnamesi, Düzenleyen: Cidde Vali Kaimmakamı Muhammed Arkî Bey, Mekkei Mükerreme, h. 1305 (1887-1888)

Hicaz Vilayeti Salnamesi, Hicaz Vilayeti Matbaas1, h. 1309 (1891-1892).

Hicaz Vilayeti Salnamesi, Mekke-i Mükerreme, h. 1303 (1885-1886).

Hicaz Vilayeti Salnamesi, Mekke-i Mükerreme, h. 1306 (1888-1889).

İmiye Salnamesi, Matbaa-i Âmire, Daru’l-Hilafeti’l-Aliyye h. 1334 (1915-1916).

Salname, Def'a 31, 1293 (1876-1877).

Salname-i Devlet-i Aliyye-i Osmaniye, 41. Def'a, Mahmud Bey Matbaası, Dersaadet h. 1303 (1885-1886). 
Salname-i Devlet-i Aliyye-i Osmaniye, 45. Sene, Matbaa-i Âmire, Dersaadet h. 1307 (18891890).

Salname-i Devlet-i Aliyye-i Osmaniye, 46. Sene, Matbaa-i Âmire, Dersaadet h. 1308 (18901891).

Salname-i Devlet-i Aliyye-i Osmaniye, 54. Sene, Âlem Matbaası ve Mahmud Bey Matbaası, İstanbul h. 1316 (1898/1899).

Salname-i Devlet-i Aliyye-i Osmaniye, 64. Sene, Matbaa-i Ahmed İhsan, Dersaadet h. 1326 (1908-1909).

Salname-i Devlet-i Aliyye-i Osmaniye, Âlem Matbaas1, Dersaadet h. 1315 (1897/1898).

\section{Books and Articles}

al-Amr, Saleh Muhammad, The Hijaz Under Ottoman Rule 1869-1914: Ottoman Vali, The Sharif of Mecca, and The Growth of British Influence, Riyad University Publications, 1974.

Arslan, Emîr Şekib, Hicaz Yolculuğu Hac Hâtıraları 1910-1940, Çeviren: Adem Yerinde, İnkılâb Yayınları, İstanbul 2012.

Aydın, Sabit, Osmanlı Döneminde Medine'de Yapılan Tarihi Eserler, Yayınlanmamış Yüksek Lisans Tezi, Erciyes Üniversitesi, Sosyal Bilimler Enstitüsü, Kayseri 2007.

Belgelerle Osmanlı Devrinde Hicaz, Volume: 1, Editör: Ömer Faruk Yılmaz, Hazırlayanlar: İlhan Ovalıoğlu, Raşit Gündoğdu at al., Çamlıca Basım Yayın, İstanbul 2008.

Bozkurt, Nebi, Küçükaşc1, Mustafa Sabri, "Mescid-i Harâm”, Türkiye Diyanet Vakfi İslâm Ansiklopedisi, Volume: 29, Türkiye Diyanet Vakf1, Ankara 2004, pp. 273-277.

Bozkurt, Nebi, Nebi; Küçükaşcı, Mustafa Sabri, "Mescid-i Nebevî”, Türkiye Diyanet Vakfı İslâm Ansiklopedisi, Volume: 29, Ankara 2004, pp. 281-290.

Cemaleddin Efendi II. Abdülhamid'in Şeyhülislâmı, Siyasi Hatıralarım, Hazırlayan: Selim Kutsan, Nehir Yayınları, İstanbul 2005.

Deringil, Selim, İktidarın Sembolleri ve İdeoloji II. Abdülhamid Dönemi (1876-1909), Çeviren: Gül Çağalı Güven, Yapı Kredi Yayınları, İstanbul 2007.

el-Betenûnî, Muhammed Lebîb, er-Rihletü'l-Hicaziyye, Mektebetü's-Sekafeti'd-Diniyye, Kahire.

el-Halidî, Dayl bin Ali, el-İdaretü'l-Osmaniyye ve Enzimetuha fi'l-Hicaz fi Ahdi's-Sultan Abdülhamid es-Sanî (h 1293-1327 / 1876-1909), Dareh el-Melik Abdülaziz, Riyad h. 1435 / m. 2014.

el-Husrî, Sat1, el-Bilâdu'l-Arabiyye ve'd-Devletü'l-Osmaniyye, Daru'l-İlm li'l-Melayin, Beyrut 1960.

Emecen, Feridun M., "Hicaz'da Osmanlı Hâkimiyetinin Tesisi ve Ebu Nümey", İ̈ Edebiyat Fakültesi, Tarih Enstitüsü Dergisi, Ayrı basım, Issue: 14, 1994, pp. 87-120.

Eraslan, Cezmi, II. Abdülhamid ve İslam Birliği, Ötüken Neşriyat A.Ş., İstanbul 2019.

Eyüb Sabri, Mir'âtü'l-Haremeyn (Mir'ât-ı Medîne), Volume: 2, Bahriye Matbaası, Kostantıniyye 1304.

Eyüb Sabri, Mir'âtü'l-Haremeyn (Mir'ât-ı Mekke), Volume: 1, Bahriye Matbaası, Kostantıniyye 1301. 
Faroqhi, Suraiya, Hacılar ve Sultanlar, Çeviren: Gül Çağalı Güven, Tarih Vakfı Yurt Yayınları, İstanbul 2008.

Findley, Carter Vaughn, Turkey, Islam, Nationalism, and Modernity, Yale University Press, New Haven \& London 2010.

Fortna, Benjamin C., Mekteb-i Hümayûn Osmanlı İmparatorluğu’nun Son Döneminde İslâm, Devlet ve Eğitim, Çeviren: Pelin Siral, İletişim Yayınları, İstanbul 2005.

Gülsoy, Ufuk, "Gerçekleşen Bir Rüya: Hicaz Demiryolu”, Osmanl, Volume: 3, Editör: Güler Eren, Yayın Kurulu Başkanı: Halil İnalcık, Yeni Türkiye Yayınları, Ankara 1999.

Gülsoy, Ufuk, Hicaz Demiryolu, Eren Yayınc1lık, İstanbul 1994.

Gülsoy, Ufuk, Kutsal Proje Ortadoğu'da Osmanlı Demiryolları, Timaş Yayınları, İstanbul 2010.

Harb, Muhammed, es-Sultan Abdülhamid es-Sâni Âhiru's-Selatini'l-Osmaniyyin el-Kibar, Daru'l-Kalem, Dımaşk (h. 1417/1996).

Hathaway, Jane, Karl K. Barbir'in katkılarıyla, Osmanlı Hâkimiyetinde Arap Toprakları, Çeviren: Gül Çağalı Güven, Türkiye İş Bankası Kültür Yayınları, İstanbul 2016.

Hicaz Demiryolu Layihası, Dersaadet, 1324.

“Hicaz Şimendifer Hattı”, İkdam, Numara: 2094, 1 Muharrem 1318 (30 Nisan 1900), p. 1.

Hoca Sadettin Efendi, Tacü't-Tevarih, Hazırlayan: İsmet Parmaksızoğlu, Volume: 4, Kültür Bakanlığı Yayınları, Ankara 1992.

Hogarth, David George, Hejaz Before World War I A Handbook, The Oleander Press, Cambridge, 1978.

Hourani, Albert, Arap Halkları Tarihi, Çeviren: Yavuz Alogan, Hazırlayan: Tanıl Bora, İletişim Yayınları, İstanbul 2007.

İbrahim Rifat Paşa, Mir'âtü'l-Haremeyn ev er-Rehelâtü'l-Hicaziyye ve'l-Hacc ve Meşa'iruhu'dDîniyye, Volume: 1-2, Matba’atü Dâri'l-Kütübi’l-Mısriyye, Kahire m. 1925 - h. 1344.

Karpat, Kemal H., İslâm’ın Siyasallaşması, Çeviren: Şiar Yalçın, İstanbul Bilgi Üniversitesi Yayınları, İstanbul 2005.

Kasım İzzeddin, Hicaz Sihhiye İdaresi Senevî Rapor Hicaz'da Teşkilat ve Islahat-ı Sihhiye 1329 Senesi Hacc-ı Şerifi, Matbaa-i Âmire, İstanbul 1328.

Kodaman, Bayram, Abdülhamid Devri Eğitim Sistemi, TTK Yayınları, Ankara 1999.

Koloğlu, Orhan, "Thomas Edward Lawrence", Kutsal Topraklarda Casuslar Savaşı, İrfan Yayımc1lik, İstanbul 1995.

Kurşun, Zekeriya, "Osmanlı Devleti İdaresinde Hicaz (1517-1919)”, Osmanl, Volume: 1, Editor: Güler Eren, Yayın Kurulu Başkanı: Halil İnalcık, Yeni Türkiye Yayınları, Ankara 1999, pp. 316-325.

Küçükaşcı, Mustafa Sabri, "Mekke" (Osmanlı Dönemi), Türkiye Diyanet Vakfi İslâm Ansiklopedisi, Volume: 28, Türkiye Diyanet Vakfi, Ankara 2003.

Landau, Jacob M., The Hejaz Railway and the Muslim Pilgrimage A Case of Ottoman Political Propaganda, Wayne State University Press, Detroit 1971.

M. Nasrullah, M. Rüşdü, M. Eşref, Osmanlı Atlası (XX. Yüzyıl Başları), Hazırlayanlar: Rahmi Tekin, Yaşar Baş, Osmanlı Araştırmaları Vakfı Yayınları, İstanbul 2003. 
Muhammed Arif, Kitabü's-Saadeti'n-Nâmiyeti'l-Ebediyyeti fi's-Sikketi'l-Hicaziyyeti'lHadidiyye, İÜ Ktp., AY, Nr. 4790.

Muhammed El-Emîn el-Mekkî, Hulefa-i I'zam-l Osmaniye Hazeratının Haremeyn-i Şerifeyndeki Âsar-ı Mebrûre ve Meşkûre-i Hümayunlarından Bahis Tarihi bir Eserdir, Matbaa-i Osmaniye, Dersaadet r. 1318 (m. 1902).

Musil, Alois, Arabia Deserta A Topographical Itinerary, Published under the Patronage of the Czech Academy of Sciences and Arts and of Charles R. Crane, New York 1927.

Ochsenwald, William, Religion, Society and the State in Arabia The Hijaz Under Ottoman Control, 1840-1908, Ohio State University Press, Columbus 1984.

Ochsenwald, William, The Hijaz Railroad, The University Press of Virginia, USA 1980.

Ortayl1, İlber, Tanzimat Devrinde Osmanlı Mahallî İdareleri (1840-1880), Türk Tarih Kurumu Yayınları, Ankara 2000.

Osmanoğlu, Abdülhamid Kayıhan, Dedem Abdülhamid Hân, Yediveren Yayınları, İstanbul 2016.

Özbek, Nadir, Osmanlı Imparatorluğu'nda Sosyal Devlet Siyaset, İktidar ve Meşruiyet 18761914, İletişim Yayınları, İstanbul 2008.

Özyüksel, Murat, "Hicaz Demiryolu”, Türkler, Volume: 14, Editör: Hasan Celâl Güzel, Kemal Çiçek, Salim Koca, Yeni Türkiye Yayınları, Ankara 2002.

Özyüksel, Murat, Hicaz Demiryolu, Tarih Vakfı Yurt Yayınları, İstanbul 2000.

Pesce, Angelo, Jiddah Portrait of an Arabian City, Oasis Publishing, 1977.

Rogan, Eugene L., II. Abdülhamid'in Aşiret Mektebi (1892-1907), Çeviren: Özkan Akpınar; Alişan Akpınar, Osmanlı Devleti'nde Aşiret Mektebi, Aşiret Mektep Devlet, Aram Yayıncıl1k, İstanbul 2001.

Sarıyıldız, Gülden, "II. Abdülhamid'in Fakir Hacılar İçin Mekke'de İnşa Ettirdiği Misafirhane”, İÜ Edebiyat Fakültesi, Tarih Enstitüsü Dergisi, Issue: 14, 1994, pp. 127-145.

Sarıyıldız, Gülden, Hicaz Karantina Teşkilâtı (1865-1914), Türk Tarih Kurumu Yayınları, Ankara 1996.

Tahsin Paşa'nın Yıldız Hatıraları Sultan Abdülhamid, Boğaziçi Yayınları, İstanbul 1999.

The Holy Qur'an With English Translation, Staff of Translation: Ali Özek, Nureddin Uzunoğlu, at al., İlmî Neşriyat, İstanbul 1992.

Uzunçarşı11, İsmail Hakkı, Mekke-i Mükerreme Emirleri, Türk Tarih Kurumu Yayınları, Ankara 1972.

Wavell, A. J. B., A Modern Pilgrim in Mecca and a Siege in Sanaa, Hazell, Watson and Viney, Ld. Constable, London and Aylesbury. 